\title{
Metasomatism and the crystallization of zircon megacrysts in Archaean peridotites from the Lewisian complex, NW Scotland
}

\author{
John W. Faithfull ${ }^{1} \cdot$ Tim J. Dempster $^{2} \cdot$ John M. MacDonald $^{2} \cdot$ Monica Reilly $^{2} \cdot$ EIMF $^{3}$
}

Received: 23 April 2018 / Accepted: 29 October 2018 / Published online: 17 November 2018

(c) The Author(s) 2018

\begin{abstract}
Zircon megacrysts are locally abundant in 1-40 cm-thick orthopyroxenite veins within peridotite host rocks in the Archaean Lewisian gneiss complex from NW Scotland. The veins formed by metasomatic interaction between the ultramafic host and Si-rich melts are derived from partial melting of the adjacent granulite-facies orthogneisses. The interaction produced abundant orthopyroxene and, within the thicker veins, phlogopite, pargasite and feldspathic bearing assemblages. Two generations of zircon are present with up to $1 \mathrm{~cm}$ megacrystic zircon and a later smaller equant population located around the megacryst margins. Patterns of zoning, rare earth element abundance and oxygen isotopic compositions indicate that the megacrysts crystallized from crustal melts, whereas the equant zircon represents new neocryst growth and partial replacement of the megacryst zircon within the ultramafic host. Both zircon types have U-Pb ages of ca. $2464 \mathrm{Ma}$, broadly contemporaneous with granulite-facies events in the adjacent gneisses. Zircon megacrysts locally form $>10 \%$ of the assemblage and may be associated to zones of localized nucleation or physically concentrated during movement of the siliceous melts. Their unusual size is linked to the suppression of zircon nucleation and increased $\mathrm{Zr}$ solubility in the Si-undersaturated melts. The metasomatism between crustal melts and peridotite may represent an analog for processes in the mantle wedge above subducting slabs. As such, the crystallization of abundant zircon in ultramafic host rocks has implications for geochemistry of melts generated in the mantle and the widely reported depletion of high field strength elements in arc magmas.
\end{abstract}

Keywords Zircon $\cdot$ Metasomatism $\cdot$ Megacrysts $\cdot$ Peridotite $\cdot$ Crustal melts $\cdot$ Lewisian

\section{Introduction}

Zircon is typically associated with crystallization from evolved igneous melts and the lack of zircon in mafic and ultramafic igneous rocks is commonly noted (e.g. Hoskin and Schaltegger 2003). However, zircon is frequently reported as xenocrysts in kimberlites (Belousova et al. 1998) and has been found in small quantities in peridotite

Communicated by Othmar Müntener.

Tim J. Dempster

Tim.Dempster@glasgow.ac.uk

1 The Hunterian, University of Glasgow, Glasgow G12 8QQ, UK

2 School of Geographical and Earth Sciences, University of Glasgow, Glasgow G12 8QQ, UK

3 EIMF (Edinburgh Ion Microprobe Facility), School of GeoSciences, Edinburgh University, Edinburgh EH9 3FE, UK from supposedly mantle wedge environments, as inherited grains from slab components (Liu et al. 2009; Li et al. 2016). Unfortunately such zircon often lacks the petrological context in which their generation in mantle peridotite might be assessed as they are either separated from their host rocks by natural processes or by sample preparation techniques. The Lewisian Gneiss Complex provides an excellent example of where the petrological context between zircon grains and ultramafic host rocks is preserved. Abundant coarse grained zircon up to $18 \mathrm{~mm} \times 9 \mathrm{~mm}$ occurs in Archaean ultramafic rocks near Loch an Daimh Mor, just south of Scourie, NW Scotland (Fig. 1). Individual mechanically separated zircon from this locality has previously been isotopically dated using the U-Pb method and yield ages of $2,470 \pm 30 \mathrm{Ma}$ (Kinny and Friend 1997) and $2451 \pm 14 \mathrm{Ma}$ (Timms et al. 2006) and the microstructures within zircon have been described from this locality (Timms and Reddy 2009). However, there has been no petrological description of the unusual occurrence. The link between large zircon and ultramafic rocks is striking both here and at other localities 
Fig. 1 Maps showing. a Location of field area within NW Scotland. b Regional geology; and $\mathbf{c}$ geological map of area around the Loch an Daimh Mor metaperidotite. White squares show the two sample locations

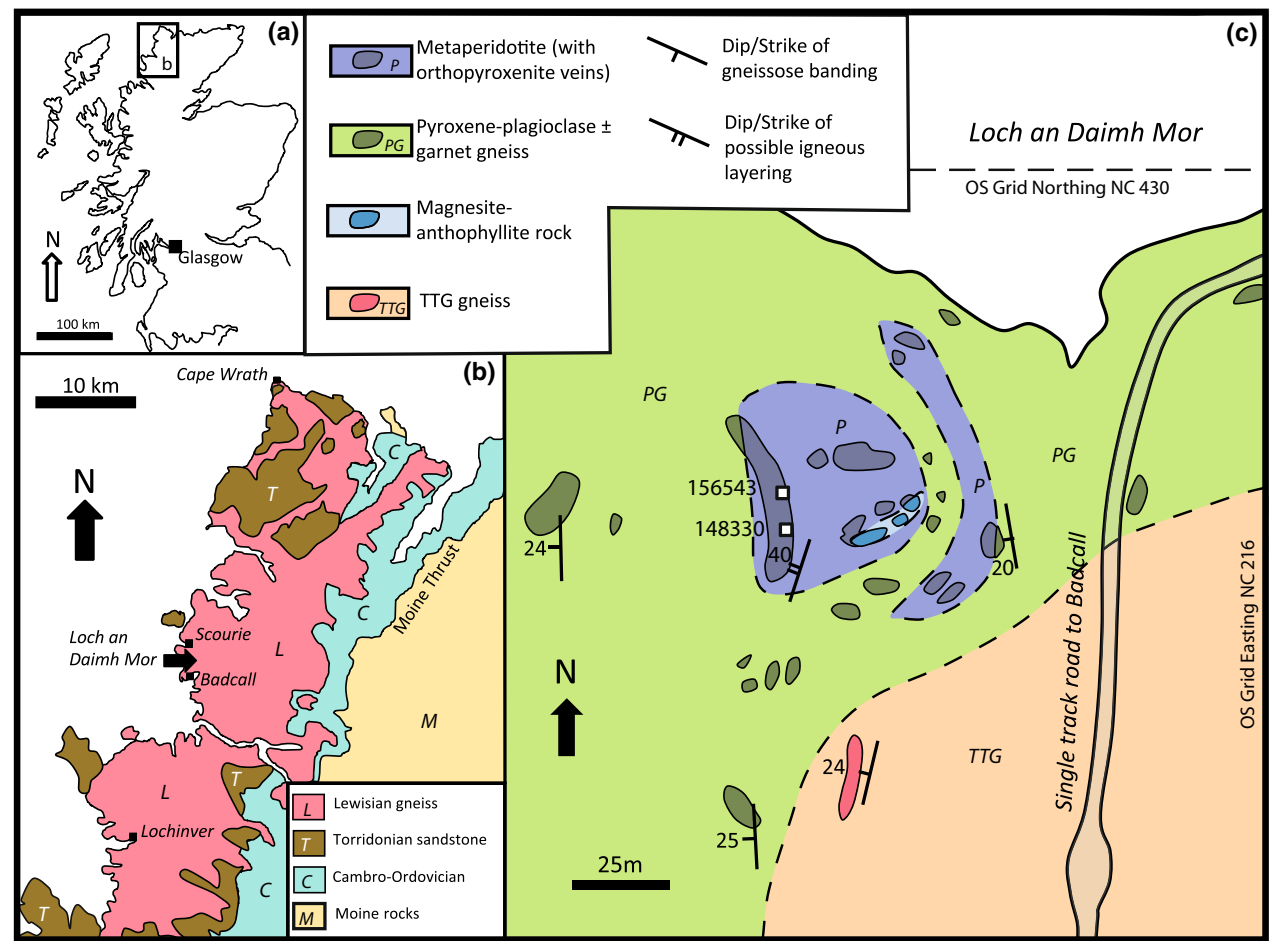

in the Lewisian rocks of Scotland (e.g. specimen from Iona in the Hunterian museum collections: GLAHM 148,080, and from Eilean Glas, Scalpay National Museums of Scotland: Dudgeon collection 74-49-245 and 246). Similar occurrences of large zircon in ultramafic rocks have also been noted elsewhere, including Greenland (Nilsson et al. 2010), Italy (Marocchi et al. 2009), and from kimberlites (Kresten et al. 1975; Belousova et al. 1998; Robles-Cruz et al. 2012). However, the relationship of zircon to the ultramafic host is often uncertain.

In this study, we investigate this in situ mineral assemblage at Loch an Daimh Mor and present new field, petrographic, microtextural, geochemical and isotopic evidence on these exceptionally large and abundant zircon crystals and describe their petrological association with the Lewisian ultramafic host rocks. We suggest that these rocks record a common process involving metasomatic interaction between crustal melts and ultramafic host rocks with potentially important implications for the geochemical behaviour of high field strength elements (HFSE) in the mantle.

\section{Geological setting and previous work}

The Lewisian Gneiss Complex (LGC) is dominantly composed of orthogneisses with tonalite-trondhjemite-granodiorite (TTG) protoliths, with subordinate mafic/ultramafic and metasedimentary gneisses (Peach et al. 1907). A number of discrete terranes are thought to be present within the gneiss complex with distinctive histories determined from structural and metamorphic field relationships and isotope geochronology (Kinny et al. 2005). The area around Loch an Daimh Mor is part of the Assynt Terrane, where zircon $\mathrm{U}-\mathrm{Pb}$ ages range from ca. $3 \mathrm{Ga}$ to $2.45 \mathrm{Ga}$, and have been variously ascribed to the formation of the igneous protolith, or to an early Badcallian metamorphic event, and/or a later Inverian event (Evans 1965; Park 1970; Corfu et al. 1994; Friend and Kinny 1995; Crowley et al. 2015). However, the difficulty in resolving and correlating the Badcallian and Inverian events in this polymetamorphic lower crustal unit is something that has plagued studies of the LGC since the inception of isotopic dating techniques (Kinny et al. 2005; Whitehouse and Kemp 2010). This confusion persists to this day in that granulite-facies metamorphism in the Assynt Terrane is commonly ascribed to the Badcallian event, but isotopic constraints also provide evidence of correlation with Inverian "age" events (Kinny et al. 2005; MacDonald et al. 2015). Despite improved analytical precision associated with zircon $\mathrm{U}-\mathrm{Pb}$ ages, it seems that a spectrum of crystallization and/or $\mathrm{Pb}$ diffusion re-equilibration ages are produced from these high-grade gneisses (MacDonald et al. 2015) with a spread of $10 \mathrm{~s}$ to perhaps $100 \mathrm{~s}$ of millions of years. It is uncertain how much this range reflects discrete separate events, or just a prolonged, if perhaps episodic, hightemperature history.

The Archaean protoliths to the gneisses around Loch an Daimh Mor have experienced a granulite-facies tectonothermal event at 2482 $\pm 6 \mathrm{Ma}$ (MacDonald et al. 2015), including partial melting (Johnson et al. 2012; Rollinson 2012), and 
locally, later amphibolite-facies event(s). Conditions during granulite-facies metamorphism nearby at Scourie are estimated to be in excess of $875^{\circ} \mathrm{C}$ and ca. 9-11 kb (Johnson and White 2011; Cartwright and Barnicoat 1987). There is some evidence that granulite-facies event(s) may have been locally preceded by eclogite-facies metamorphism, with omphacite-bearing assemblages surviving in garnetrich clots within some metagabbros (Sajeev et al. 2013), but the regional extent of this remains unclear. Later, at ca. $2400 \mathrm{Ma}$, the mafic Scourie Dyke Swarm was intruded (Heaman and Tarney 1989; Davies and Heaman 2014) postdating the local granulite-facies events. The final episodes of tectonothermal activity occurred in Laxfordian events at ca. 1740 and $1670 \mathrm{Ma}$ (Goodenough et al. 2013), characterized by shear zones and amphibolite facies retrogression.

The ultramafic bodies at Loch an Daimh Mor (Fig. 1b) occur ca. $2 \mathrm{~km}$ to the south of Scourie and were described by Peach et al. (1907), Bowes et al. (1964), and O'Hara (1961, 1965). They are surrounded by coarse grained granulitefacies garnet-clinopyroxene-plagioclase \pm orthopyroxene mafic gneisses (Fig. 1c), probably metagabbros, and twopyroxene tonalitic and mafic-banded orthogneisses (Rollinson and Windley 1980) with occasional metasedimentary xenoliths (Davies 1974). The ultrabasic bodies and adjacent mafic gneisses are considered to have experienced the same metamorphic grade (O'Hara 1961; Bowes et al. 1964; Sills et al. 1982). However, due to their different mineralogy, it is difficult to match metamorphic responses in the regional TTG gneisses to responses within the peridotite. The relative ages of the ultramafic bodies and the surrounding TTG gneisses are ambiguous. Many, especially the pyroxenitedominated bodies, are probably later intrusive sills (Guice et al. 2018), but others (possibly including Loch an Daimh Mor) may be older than the host gneisses. For example, at "First Inlet", just north of Scourie, a small ultramafic body is cut by a trondhjemite vein with 2955 Ma protolith zircon ages, similar to ages from the host TTG gneisses (Friend and Kinny 1995).

The presence of large zircon at Loch an Daimh Mor was first noted by mineral collectors such as Gordon Sutherland and Kemp Meikle in the 1960s. Specimens, from this time, usually labelled "Badcall", are not uncommon in museum and private mineral collections in Scotland. The first published work on the zircon was by Kinny and Friend (1997), whose sample GST15 is described as "a large zircon $12.5 \mathrm{~mm}$ long hosted by pyroxenite from the margin of one of a series of ultrabasic/mafic bodies at Loch an Daimh Mor". This sample has since been the subject of a range of other investigations including the effects of crystal plastic deformation of the large subhedral zircon (Timms and Reddy 2009) and U-Pb geochronology which yielded an age of 2,451 $\pm 14 \mathrm{Ma}$ (Timms et al. 2006). Timms and Reddy (2009) stated that the deformation of the "syntectonic pyroxenite intrusion" hosting sample GST15 was associated with regional amphibolite-facies Inverian metamorphism. A brief note from a mineral collecting perspective has been published by Moffat and Starkey (2013). We present here the first detailed geological account of this ultramafic-hosted zircon occurrence.

\section{Field observations}

\section{The Loch an Daimh Mor peridotite}

The peridotite occupies a total area of ca. $2500 \mathrm{~m}^{2}$ (Fig. 1c) and this study reports on relationships around UK grid reference NC1591 4291. Although the level of exposure is such that the geometry of the peridotite is uncertain, two sheet-like bodies are thought to be present aligned roughly parallel to the gently inclined foliation in the surrounding gneisses (Fig. 1c). A thin lower sheet of ca. $5 \mathrm{~m}$ thickness and an upper sheet of ca. $10 \mathrm{~m}$ thickness occur within garnet-rich pyroxene gneisses. Locally, concentrations of spinel occur within the peridotite with individual grains/ clusters up to $1 \mathrm{~cm}$. These may represent original igneous layering, which generally seems to be sub-parallel to the dominant regional fabric in the host gneisses (Fig. 1c). Only the lower boundary of the lower peridotite body is clearly exposed: serpentinized peridotite is interbanded on a cm-scale with garnet-rich pyroxene gneisses with a similar dip. The peridotite is typically close to dunite, with unfoliated, coarsely granoblastic olivine around 1-2 mm in diameter.

Partial alteration of olivine to serpentine is ubiquitous, with slickensided surfaces on fractures. An area dominated by anthophyllite-magnesiteanthophyllite-magnesite-talc assemblages (O'Hara 1965) occurs within the upper peridotite body (Fig. 1c), with coarse $0.5 \mathrm{~cm}$ randomly oriented anthophyllite needles present in $0.5 \mathrm{~m}$ diameter patches between $10 \mathrm{~cm}$ thick carbonate-rich veins. The anthophyllite-magnesite rock represents pervasively altered peridotite, retrogressed in lower amphibolite facies conditions, with high $\mathrm{H}_{2} \mathrm{O}$ and $\mathrm{CO}_{2}$ activity (Ford and Skippen 1997). Locally, sub-parallel $10 \mathrm{~cm}$ veins of this carbonated material cut serpentinized peridotite with sharp contacts. No lowtemperature hydrous minerals equivalent to the anthophyllite-, or serpentine-bearing assemblages in the peridotite have been identified in the adjacent host gneisses. The only obvious retrograde effects are rare $<10 \mathrm{~cm}$ green amphibole-filled fractures in granulite-facies gneisses. Although the TTG and mafic gneisses are inherently less reactive than the peridotite to retrograde metamorphism, it is uncertain how the peridotite assemblages might relate to events in surrounding gneisses, or indeed how the required fluxes of $\mathrm{H}_{2} \mathrm{O}$ and $\mathrm{CO}_{2}$ entered the peridotite through those gneisses. 


\section{Veins in the Loch an Daimh Mor peridotite}

Orange-brown cross cutting orthopyroxenite veins are the dominant structures present within the peridotite (Fig. 2). The veins are also partially altered to serpentine along both fractures and grain boundaries. The veins are common throughout the peridotite body, although present in greatest abundance $(>20 \%)$ in parts of the larger upper body. The orthopyroxenite veins range in thickness from ca. $1 \mathrm{~cm}$ up to $40 \mathrm{~cm}$. They locally form networks (Fig. 2a, c), and typically occur as roughly planar sheets that can be traced over several metres. However, irregular-shaped veins are also present (Fig. 2b). Many veins dip at shallow to moderate angles to the northwest, but they are also in a range of other orientations forming sheets between blocks of the host peridotite. Some have an apparently folded geometry whilst others are displaced across minor fractures. Locally, veins cross-cut (Fig. 2c) but no consistent sequence of emplacement linked to orientation is identified. Larger volumes of orthopyroxenite are typically developed at the junctions between vein sets and tend to have the least regular geometry (Fig. 2b). Contacts between the orthopyroxene veins and the host peridotite are typically sharp. Most of the veins contain largely unfoliated, coarse (ca. $500 \mu \mathrm{m}$ ) granular pale grey orthopyroxene, with a little sulphide and locally abundant zircon megacrysts. However many show late fractures of a locally consistent orientation associated with serpentine alteration. Locally up to $1 \mathrm{~cm}$ orthopyroxene megacrysts are present in the veins and show marginal recrystallization to the more typical granoblastic orthopyroxene (Fig. 3a).
A few veins show a complex symmetrically zoned assemblage involving a sequence, or more typically partial sequence, of low-variance mineral assemblages (Fig. 2b, d). The thicker veins have both the most complete set of assemblages and the thickest individual zones, although the thickness of individual zones varies between different veins. The zoned veins are characterized by an outer margin (ca. $5 \mathrm{~cm}$ ) of granoblastic orthopyroxenite (Fig. 3a, b), identical to that present in all of the veins. Typically the zoned veins contain a prominent central zone of dark green granoblastic clinopyroxene and pargasite (ca. $1.5 \mathrm{~mm}$ grains) with minor plagioclase that is a few $\mathrm{cm}$ thick but may be up to $20 \mathrm{~cm}$ (Fig. 2d). Clinopyroxene often appears as isolated inclusions within pargasite and as finer grained clusters surrounded by pargasite (Fig. 3d). The pargasite is both finer grained and shows shape alignment towards the more central parts of the vein. In some of the thicker veins, phlogopite (up to $5 \mathrm{~mm}$ ) may be present in a thin $\mathrm{cm}$-scale zone with orthopyroxene at the junction with an inner clinopyroxene/ pargasite zone (Fig. 3a). The largest vein contains additional central plagioclase-bearing zones. An outer ca. $2 \mathrm{~cm}$ thick zone characterized by a symplectite-like intergrowth between aligned ca. $1 \mathrm{~mm}$ long euhedral phlogopite, with cleavage planes typically perpendicular to the vein margin, coarse grained (ca. $0.5 \mathrm{~mm}$ ) clinopyroxene and plagioclase (Fig. 3a, e). Inside this, a zone with aligned phlogopite has a gradational contact with an inner ca. $1.5 \mathrm{~cm}$ thick zone where ca. $0.5 \mathrm{~mm}$ scapolite, clinopyroxene, plagioclase and less abundant phlogopite coexist (Fig. 3f). Trace amounts of apatite (up to $100 \mu \mathrm{m}$ ) and rutile are present typically
Fig. 2 Field photographs of orthopyroxenite veins within the host peridotite. a Network of brown-orange orthopyroxenite. Hammer head is $20 \mathrm{~cm}$ long. b Irregular orthopyroxenite vein with central green clinopyroxene. Compass clinometer is $10 \mathrm{~cm}$ long; c Orthopyroxenite veins showing cross cutting relationships. Hand lens is $5 \mathrm{~cm}$ long; d Symmetrically zoned pyroxenite vein with central clinopyroxene (Cpx) and phlogopite zone and marginal orthopyroxene (Opx); e Hand specimen of serpentinized orthopyroxenite with several large pink zircon ( $\mathrm{Zrn})$ megacrysts

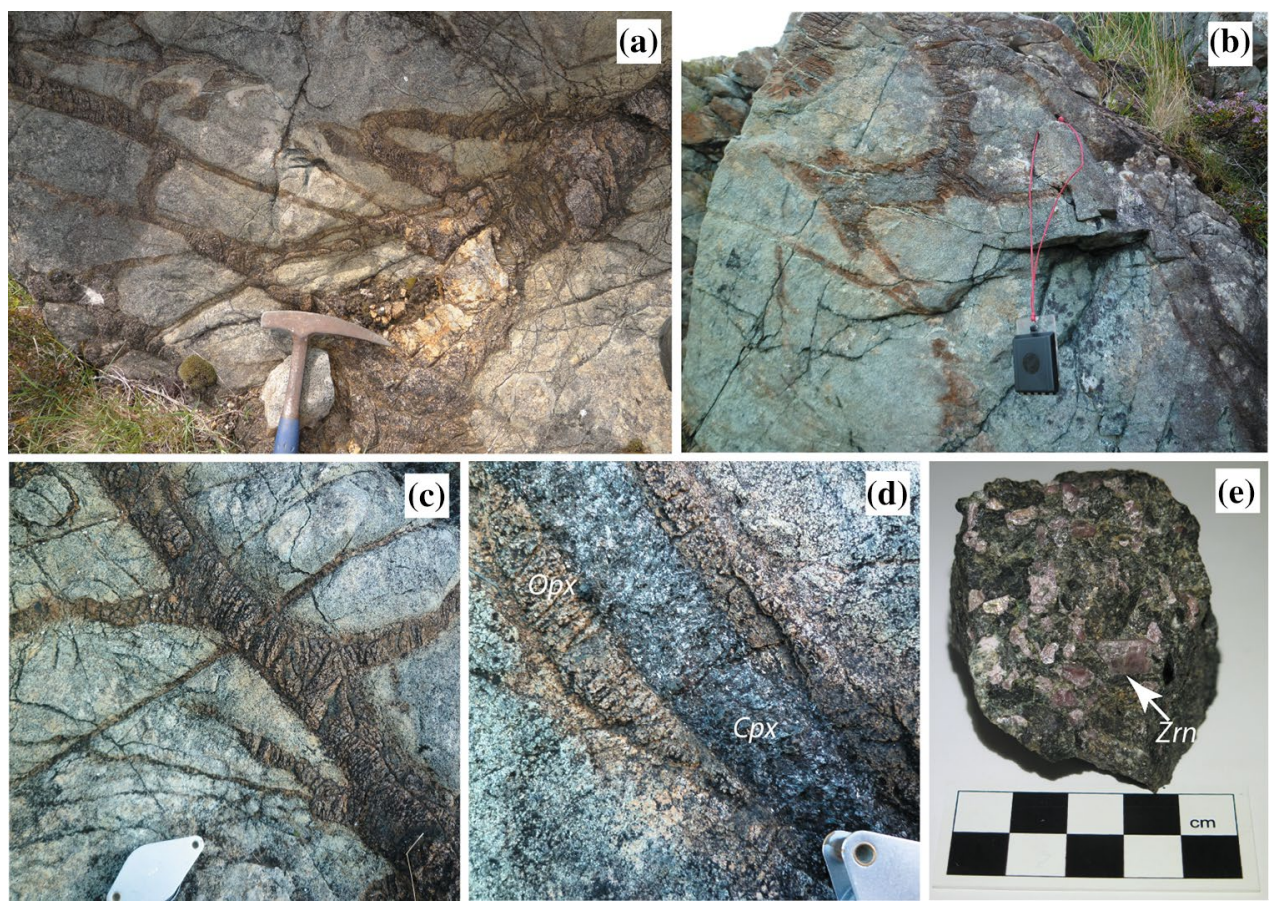


within the phlogopite-rich zones. In this vein, there is a central core of leucomonzonite composed of coarse grained (0.5-1 mm) plagioclase and perthitic K-feldspar (Fig. 3a, g). Phlogopite typically shows patchy minor alteration to chlorite and calcite, and clinopyroxene may show patchy marginal retrogression to tremolite-actinolitic amphibole (Fig. 3e). Typically little alteration to serpentine occurs although some retrogression of original probable pyroxene is locally present in the zone with phlogopite-clinopyroxene-plagioclase intergrowths. The zoned structure does not extend along the full length of the vein but internal zones are laterally discontinuous and occur as isolated ellipsoids of variable length (Fig. 2b, d). This is most obvious with those veins containing just the additional clinopyroxenite central portion as they typically have the simplest geometry. Orthopyroxenite veins within the anthophyllite-magnesite rock body have an identical morphology to those in the adjacent peridotite, but appear to have been converted to pale fibrous amphibole-rich assemblages.

Large ( $\mathrm{mm}$ to $\mathrm{cm}$ sized) pink zircon is visible in the field in several orthopyroxenite veins (Fig. 2e) within both of the peridotite bodies. Such megacrysts are difficult to observe on weathered surfaces, but are obvious on fresh surfaces. Zircon distribution was also assessed across field exposures at night using shortwave (254 nm) UV light as the mineral fluoresces bright yellow. Zircon is associated with either orthopyroxenite veins in the peridotite, or orthopyroxenite patches in deformed serpentinized peridotite (Fig. 3a-c). It is not present in the host peridotite and UV examination of the adjacent gneiss does not show large zircon megacrysts or abundant zircon. Coarse grained zircon is most abundant (up to $15 \%$ volume) in phlogopite-bearing orthopyroxenite but is also present in the pure orthopyroxenite typically close to the phlogopite-orthopyroxene zone (Fig. 3a, c). Zircon is occasionally present in the phlogopite-rich clinopyroxeniteand scapolite-bearing zones (Fig. 3f) but is absent from the central feldspathic zone. Typically the zircon megacrysts have a strongly clustered distribution within individual veins and lack obvious alignment (Fig. 2e). Isolated zircon rarely occurs within serpentinite, but always adjacent to orthopyroxenite. Most of the thinner orthopyroxenite veins do not contain obvious zircon, but where zircon occurs it is typically very abundant (Fig. 2e), and zircon-rich veins can be traced for several metres.

\section{Methods}

Zircon morphology was characterized in polished thin sections by backscattered electron (BSE) and cathodoluminescence imaging using a FEI Quanta 200F field emission environmental scanning electron microscope operated at 20 kV. Composite BSE-reflected light-cathodoluminescence images that display the zoning and growth/alteration textures in the zircon were used to guide all subsequent chemical and isotopic analyses. Associated silicate minerals were analysed using the Carl Zeiss Sigma VP electron microscope SEM operated $20 \mathrm{kV}$, at the University of Glasgow. Major elements were measured by EDAX, using Oxford INCA software, and jadeite ( $\mathrm{Na}, \mathrm{Al})$, rhodonite $(\mathrm{Mn})$, garnet $(\mathrm{Fe})$, diopside $(\mathrm{Ca})$, periclase $(\mathrm{Mg})$, chromite $(\mathrm{Cr})$ and rutile (Ti) standards, with a $10-\mu \mathrm{m}$ spot size to minimize sample heating effects. Nickel in olivine was measured using a WD detector, and $\mathrm{Ni}$ metal standard. $\mathrm{Cl}$ and $\mathrm{S}$ analysis of scapolite was carried out without standards using inbuilt calibration of INCA software.

The trace element and isotope geochemistry of the zircon was determined by SIMS analysis at the NERC Ion Microprobe Facility, University of Edinburgh. Trace elements were measured using a Cameca IMS-4F ion microprobe. Analytical and correction procedures follow those outlined by Kelly and Harley (2005) and Kelly et al. (2008). Analytical reproducibility of trace elements was calibrated against the 91,500 and SL1 zircon standard and the NIST SRM610 glass standard (Hinton 1999). For most REEs (middleheavy), the average analytical error was $<10 \%(2 \sigma)$, but for some for the lighter REEs which have lower concentrations (La, Pr, Nd, Sm), it was higher. Analytical reproducibility

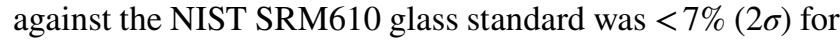
all analysed trace elements.

Oxygen isotope data were acquired at the University of Edinburgh with a Cameca IMS 1270 (\#309), using a 5 nA primary ${ }^{133} \mathrm{Cs}^{+}$beam. Secondary ions were extracted at $10 \mathrm{kV}$, and ${ }^{16} \mathrm{O}^{-}\left(\sim 3.0 \times 10^{9} \mathrm{cps}\right)$ and ${ }^{18} \mathrm{O}^{-}\left(\sim 4.0 \times 10^{6} \mathrm{cps}\right)$ were monitored simultaneously on dual Faraday cups (L'2 and H'2). Each analysis involved a pre-sputtering time of $60 \mathrm{~s}$, followed by automatic secondary beam and entrance slit centring and finally data collection in two blocks of ten cycles, amounting to a total count time of $80 \mathrm{~s}$, with an analysis diameter of ca $15 \mu \mathrm{m}$. The external precision of each analysis is $<0.2 \%$. To correct for instrumental mass fractionation (IMF), all data were normalized to a Zircon Standard 91,500 (Wiedenbeck et al. 2004) mounted together with the samples and measured throughout the analytical sessions. The internal precision is estimated from the repeat analysis of the standard to be $<0.17 \%$.

$\mathrm{U}-\mathrm{Pb}$ isotopic determinations were also acquired using the Cameca IMS 1270 and follow methods described in Kelly et al. (2008) and ratios were calibrated against 91,500 zircon (Wiedenbeck et al. 2004). Reproducibility on standard measurements during the analysis was ca $1 \%(1 \sigma)$. Analysis spot size was ca $25 \times 30 \mu \mathrm{m}$. Concordia plots and age calculations follow Ludwig (2003). Common $\mathrm{Pb}$ corrections (typically $<10 \mathrm{ppb}$ ) were determined using ${ }^{204} \mathrm{~Pb}$ and potential surface contamination reduced by routinely discarding the first five sets in the analytical cycle. 

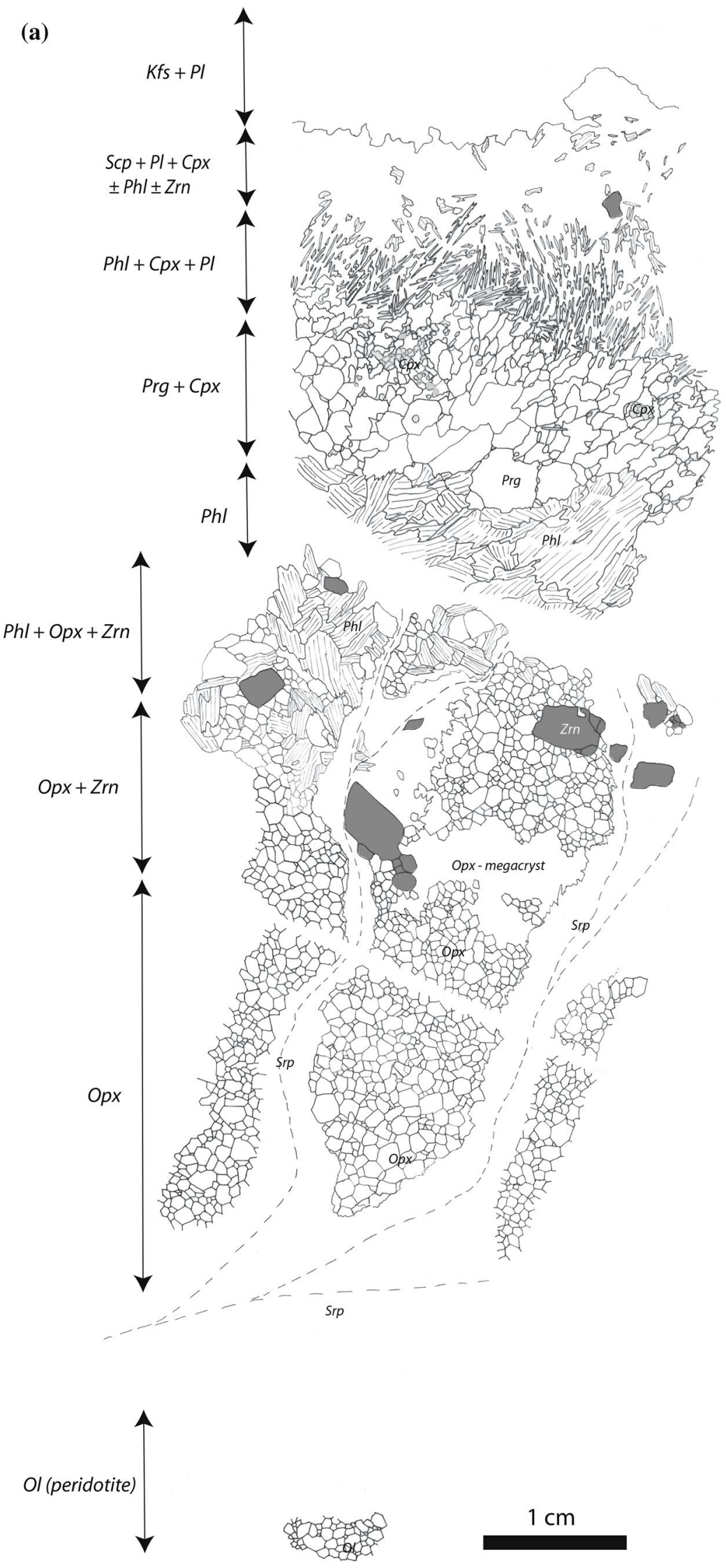
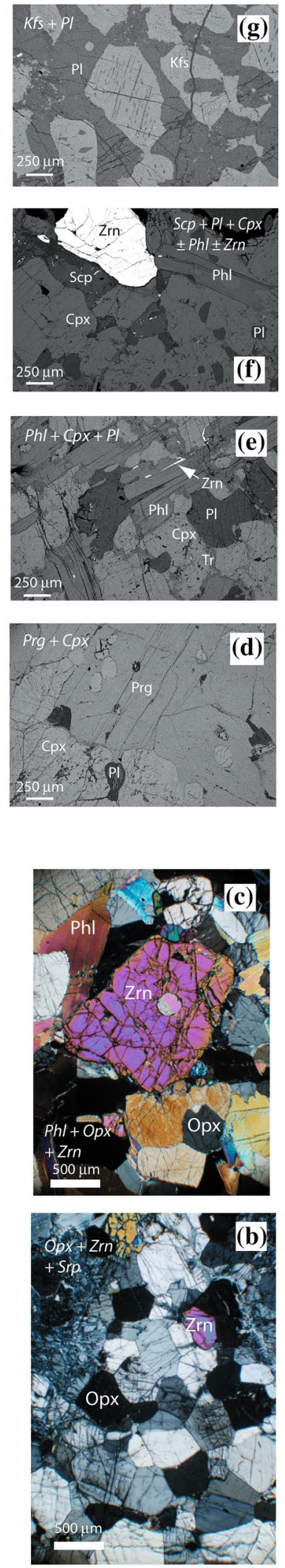
4Fig. 3 a Composite sketch showing petrography of thin sections from zoned orthopyroxenite vein with locations of zircon ( $\mathrm{Zrn}$-shaded) shown relative to different mineral assemblage zones labelled on lefthand side of the figure. Later veins of serpentinite (Srp) are common within both the host peridotite and the orthopyroxene veins. Transitions between some zones are absent due to either sample loss during thin section preparation or extensive serpentinization. Mineral abbreviations follow Whitney and Evans (2010). Each of the associated figures $\mathbf{b}-\mathbf{g}$ is labelled in italics with the corresponding mineral zone of the zoned vein. b Photomicrograph of zircon megacryst within granoblastic orthopyroxenite (crossed polarized light); $\mathbf{c}$ photomicrograph of large zircon megacryst in phlogopite-orthopyroxene zone (crossed polarized light); $\mathbf{d}$ backscattered electron image of pargasite-clinopyroxene zone with minor altered interstitial plagioclase, and inclusions of pyroxene within pargasite. Clinopyroxene shows marginal alteration to tremolite-actinolite; e backscattered electron image of phlogopite-clinopyroxene-plagioclase zone with aligned phlogopite. Marginal alteration of pyroxene to tremolite-actinolite (Tr). Thin zircon locally occupies the cleavage of phlogopite (arrowed); $\mathbf{f}$ backscattered electron image showing isolated large zircon within scapolite-plagioclase-clinopyroxene zone; $\mathbf{g}$ backscattered electron image of leucomonzonite central part of the zoned vein with granoblastic plagioclase and perthitic orthoclase

Analysed samples (GLAHM 148,330, 156,543) and other representative material are deposited in the Hunterian, University of Glasgow.

\section{Results}

\section{Zircon textures}

Two main generations of zircon are present within the orthopyroxenite veins: larger megacrysts and smaller equant zircon. Large $\mathrm{cm}$-sized subhedral to euhedral zircon megacrysts (Fig. 4a, c) are abundant in some veins with locally well-developed concentric fine-scale $(1-100 \mu \mathrm{m})$ oscillatory zoning (Fig. 4c). This zoning in cathodoluminescence is typically most well developed in the thick (up to $1 \mathrm{~mm}$ ) outer mantles of the megacrysts around an apparently more uniform core. All boundaries between core and mantle zones are approximately parallel to the megacryst edge. Sector zoning is present in some grains typically with brighter luminescence zones radiating towards the corners (Fig. 4c, g). Outer zones of the megacrysts contain broader zones locally with dark luminescent outer rim of between 30 and $400 \mu \mathrm{m}$ thickness (Fig. 4a, c). This rim may either have a sharp, locally cross-cutting, contact with the internal zones or there may be a continuous transition into the brighter internal zones. Locally the zircon megacrysts contain a thin (ca. $20 \mu \mathrm{m}$ ) discontinuous more brightly luminescent zone on the outer edge (Fig. 4c), either when in contact with other silicates or in contact with other zircon. The dark CL outer rims are cut across by both the equant zircon and the local outer bright $\mathrm{CL}$ rims. Inclusions of orthopyroxene and more commonly phlogopite, up to $500 \mu \mathrm{m}$, are present, which may alter to serpentine in some instances. Smaller inclusions, both mineral and probably fluid, may form linear arrays within the zircon host associated with fractures filled by more strongly luminescent zircon. The zircon megacrysts are characterized by several generations of fractures (Fig. 4a, c, e, f), also noted in the studies of Timms et al. (2006), Rimsa et al. (2007) and Reddy et al. (2006). Cathodoluminescence images show that the large zircon is commonly pervasively fractured, typically with no or very minor shear displacement, although some larger serpentine-filled fractures are associated with brecciation and displacements up to $1 \mathrm{~mm}$ (Fig. 4e). A variety of different fracture types are present: pervasive, branching fractures of random orientation characterized by dark luminescent zircon of a few microns to tens of microns width (Fig. 4a); fractures with more consistent orientation filled by bright luminescent zircon (Fig. 4a); and sets of concentric fractures centred on points at the edges of some zircon. The intense fracturing may create a blocky style of zoning in the cores of some large megacrysts, with broad fracture-related zones of dark luminescent zircon superimposed on areas with oscillatory zoning (Fig. 4a). Bright luminescent zircon-filled fractures may be in continuity with the thin zones of bright luminescent zircon forming at the very edge of the large zircon. Such brightly luminescent zircon may also form a thin (ca. 20-50 $\mu \mathrm{m}$ ) edge of the zircon adjacent to the larger inclusions (Fig. 4f) and is often associated with an adjacent dark inner zone of similar width. Some fractures associated with bright luminescent zircon may follow consistent crystallographic orientations within the zircon and show an asymmetric pattern of bright luminescent zircon either side of the plane (Fig. 4g).

A generation of smaller $(100-500 \mu \mathrm{m})$ equant zircon form clusters or aligned trails around margins of larger megacrysts (Fig. 5). These have a granoblastic texture within each cluster (Fig. 5b) and also commonly occur as individual partially enclosed inclusions within the outer margins of the larger grains (Fig. 4a). Some of these granular inclusions are located in consistent crystallographic positions at the corners of the megacrysts but there is no obvious relationship between the crystallographic orientation of the megacrysts and that of the later granular zircon. The equant zircon that occurs within the edge of the megacrysts are typically larger than those occurring in the adjacent clusters. Locally the small equant zircon appears to be evenly spaced along the edge of the large zircon and the edge of the latter protrudes towards the former (Fig. 5d), forming a partial or complete isthmus between the two. The equant zircon is characterized by rather darker luminescence than the megacrysts, and has broad $(50-100 \mu \mathrm{m})$ diffuse concentric zones typically with a darker luminescent core and brighter rim (Fig. 5a-c). The zones are not sharply concentric but are typically smoothly curving broadly parallel to the grain boundaries (Fig. 5a). Isolated equant zircon lacking contact with other zircon 


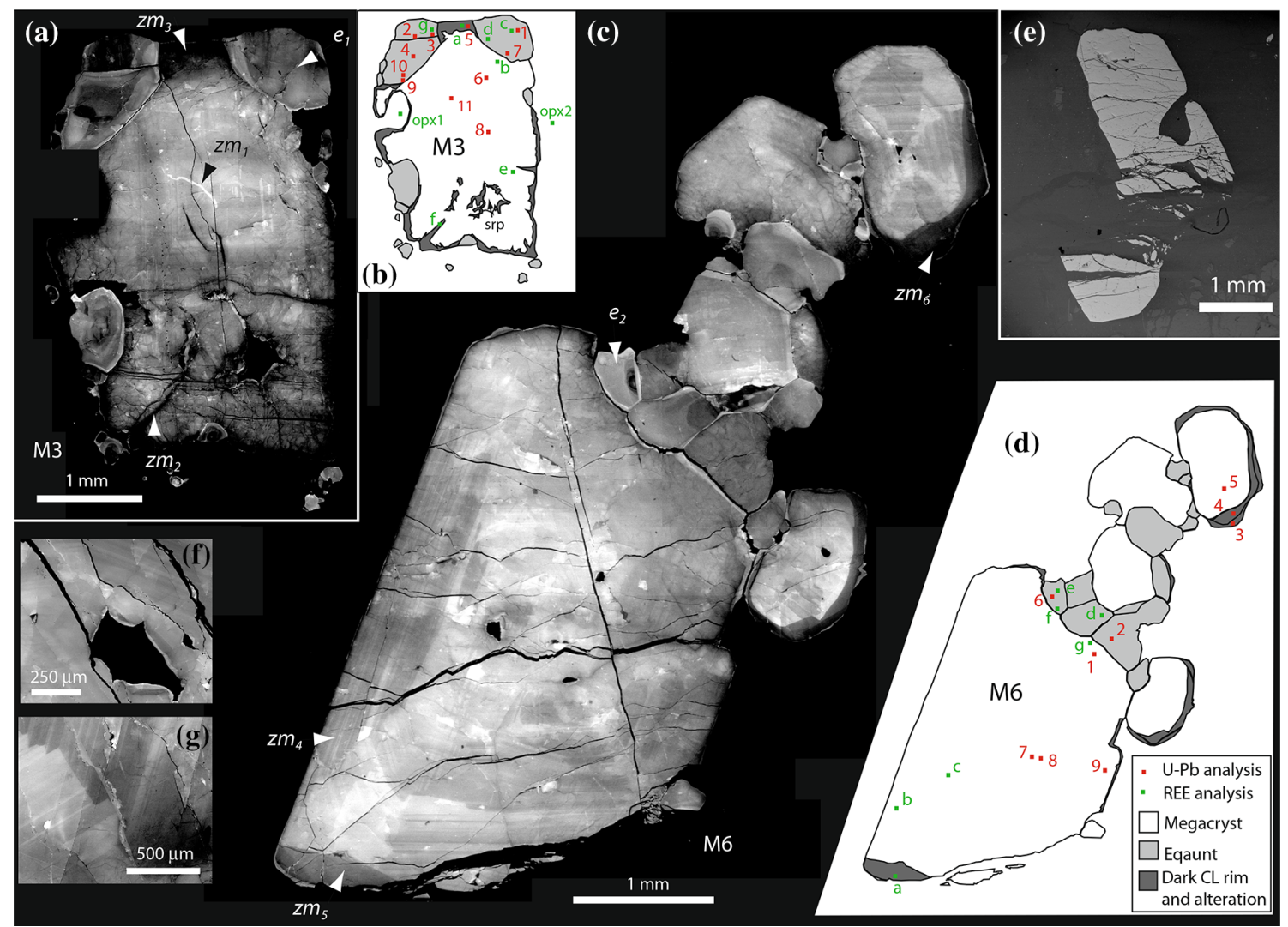

Fig. 4 Cathodoluminescence images (unless otherwise stated) of zircon megacrysts. a Large megacryst (M3) with irregularly zoned and fractured interior, equant granular zircon forms partial inclusions around the top corners and lower left-hand side. $\mathrm{zm}_{1}$-oscillatory zoned megacryst core with bright $\mathrm{CL}$ fracture fill; $\mathrm{zm}_{2}$-dark $\mathrm{CL}$ fracture fill in irregularly fractured megacryst host; $\mathrm{zm}_{3}$-dark $\mathrm{CL}$ altered rim to megacryst; $\mathrm{e}_{1}$-zoned equant zircon with bright $\mathrm{CL}$ rim on inner margin. b Cartoon representation of zircon M3 showing main types of zircon and locations of $\mathrm{U}-\mathrm{Pb}$ and $\mathrm{REE}$ analyses. c Large zircon megacryst (M6) with well-developed oscillatory zoning, marginal modification producing equant granular zircon. $\mathrm{zm}_{4}-$ oscillatory zoned megacryst with irregular zoning in the core area; $\mathrm{zm}_{5}$-dark CL marginal alteration to large megacryst; $\mathrm{zm}_{6}$-dark CL overgrowth to small sector zoned megacryst zircon with fine-scale irregular fractures; $\mathrm{e}_{2}$-zoned equant zircon with bright CL rim. d Cartoon representation of zircon M6 showing main types of zircon and locations of $\mathrm{U}-\mathrm{Pb}$ and REE analyses. e Fractured megacryst showing displacement along serpentine-filled fractures (Backscattered electron image). f Zoned, fractured zircon showing bright CL modification around phlogopite inclusion (dark CL). g Oscillatory zoned zircon with bright, altered zircon showing crystallographic control on the modification either side of the central fracture typically shows concentric zoning geometry (Fig. 5d), whereas those adjacent to other zircon, whether megacrystic or granular types, typically show asymmetric zoning, with a geometry either indicative of growth out from a granoblastic cluster (Fig. 5c) or growth towards the megacrystic "host" grain (Fig. 5a). As with the megacryst zircon, edges of the equant zircon are commonly characterized by a bright rim that is present between the inclusions and the host grain and between the smaller grains in clusters around the megacrysts (Fig. 5c). The smaller equant zircon is characterized by less fracturing, especially those fractures filled by the darker CL zircon. Some serpentine-filled fractures are present and those filled with bright luminescence zircon may be in continuity with the local bright luminescent rims (Fig. 5c).

The phlogopite-rich zones of the orthopyroxenite vein contain a rare third form of zircon, which was not analysed.
This "skeletal" thin $(20 \mu \mathrm{m})$ elongate $(300 \mu \mathrm{m})$ zircon occurs between [001] cleavage planes of phlogopite and extends along adjacent grain boundaries (Fig. 3e).

\section{Mineral chemistry}

The major element compositions of minerals from the host peridotite and the orthopyroxenite vein assemblage are presented in Table 1. Olivine in the peridotite has a composition $\mathrm{Fo}_{87}$, and those other ferro-magnesian mineral phases in the vein assemblage are similarly Mg-rich. Hence, the orthopyroxene has $\mathrm{Mg}$ \# of 86.5-87.6, with an $\mathrm{Al}$ content of 2.6-3.6\% $\mathrm{Al}_{2} \mathrm{O}_{3}$. Generally, the $\mathrm{Mg}$ numbers of both clinopyroxene (and phlogopite $(88-84)$ decrease slightly towards the centre of the zoned veins (Table 1) and plagioclase is progressively more sodic $\left(\mathrm{An}_{55}\right.$ to $\left.\mathrm{An}_{35}\right)$ within the 
Fig. 5 Cathodoluminescence images of equant granular zircon. a Two large equant zircons adjacent to fragment of fractured megacryst zircon (left side of image). b Cluster of zoned equant zircon with granoblastic texture and both concentric and asymmetric zoning. $\mathbf{c}$ Zoned granular zircon containing a range of different fracture types with both dark and light CL fill. d Megacryst zircon with smaller equant zircon present around right hand margin, showing thin isthmus of late zircon growth joining the equant and megacryst zircon

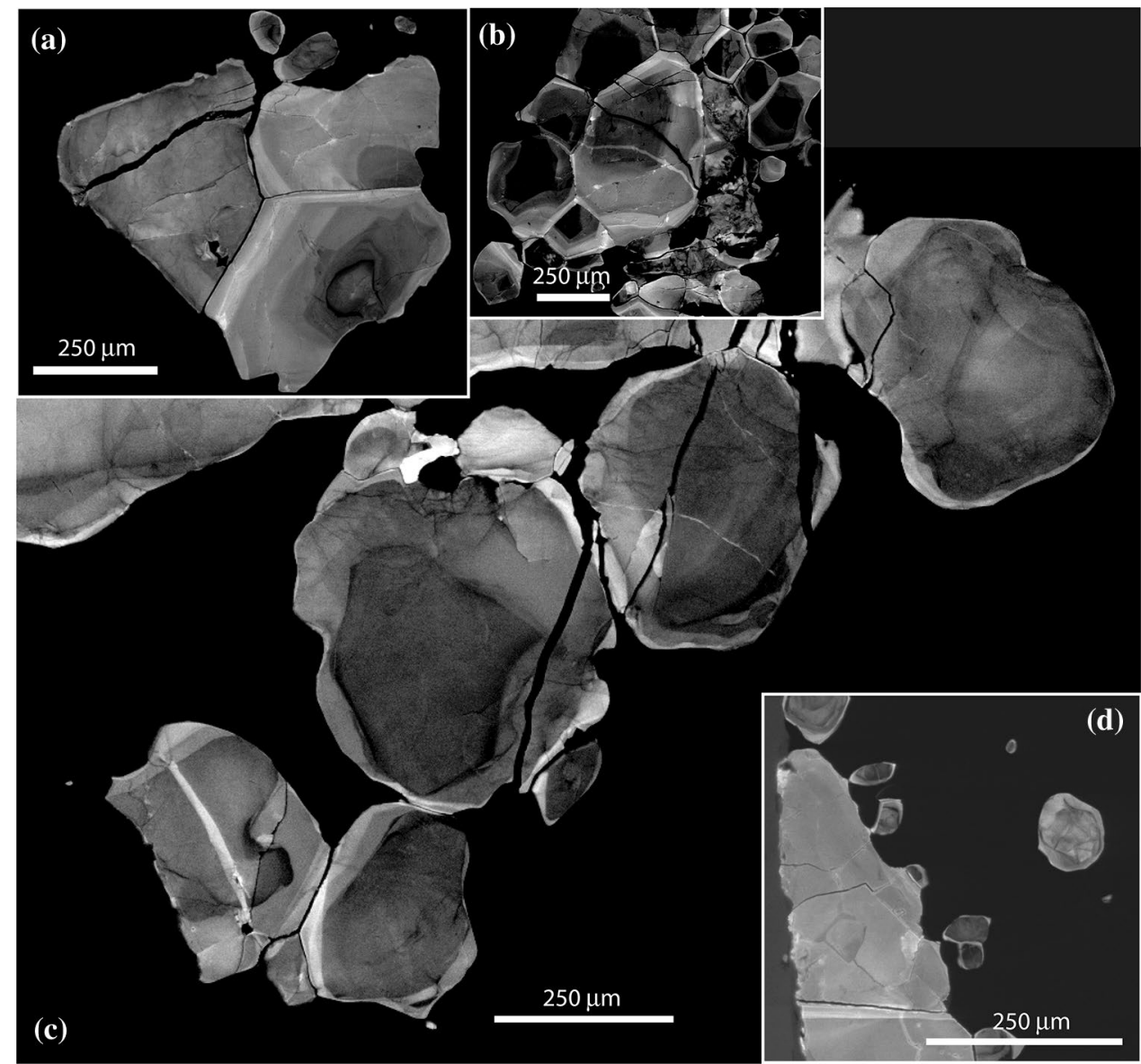

more central zones (Table 1). Most phases themselves are chemically unzoned in the veins, although minor marginal retrogression of the diopside-rich clinopyroxene occurs, producing a $\mathrm{Mg}$-rich hornblende. Rare spinels within the orthopyroxenite have a $\mathrm{Cr} /(\mathrm{Cr}+\mathrm{Al})$ of 0.22 . Scapolite is relatively $\mathrm{Ca}$-rich with a $\mathrm{Ca} /(\mathrm{Ca}+\mathrm{Na})$ of 0.73 , with $\mathrm{SO}_{3}$ up to ca $7 \%$ (cf. Teertstra et al. 1999).

\section{Trace elements}

The two main populations of zircon, megacrystic and equant types are characterized by relatively consistent and distinctive trace element geochemistry. All of the zircon from the orthopyroxenites have consistent Hf contents of $8617 \pm 374 \mathrm{ppm}(2 \sigma$ error) (Table 2$)$, irrespective of textural type.

The zircon megacrysts have relatively high total REE contents (av. $201 \mathrm{ppm}$ ), high $Y$ contents (408-223 ppm), positive $\mathrm{Ce}$-anomalies $(\mathrm{Ce} / \mathrm{Ce} *=57.8)$, and negative $\mathrm{Eu}$ anomalies $\left(\mathrm{Eu} / \mathrm{Eu}^{*}=0.28\right)$ (Fig. 6) (Table 2) in comparison to the equant zircon. The chondrite-normalized REE profiles of the megacrysts (Fig. 6) show characteristically high $\mathrm{Sm} / \mathrm{La}$ ratios (65.9) and low $\mathrm{Lu} / \mathrm{Gd}$ ratios (17.9). Ti contents of the zircon megacrysts range from 6.5 to $12.1 \mathrm{ppm}$.
Luminescence intensity generally shows an inverse correlation with actinide content, but is unrelated to other trace elements. Dark luminescence zircon associated with fracturing and late alteration is characterized by typically 2-3 times higher $\mathrm{U}$ and $\mathrm{Th}$ contents with slightly higher $\mathrm{Th} / \mathrm{U}$ (mean $=1.07$ ) than the brighter CL zones of the megacrysts (mean $\mathrm{Th} / \mathrm{U}=0.78$ ). As such the actinides appear to be the most mobile of the trace elements within zircon (Timms et al. 2006).

The smaller, equant zircon grains form a geochemically distinct population characterized by consistently low total REE contents (av. 34 ppm), and correspondingly low Y (50-72 ppm). They lack a marked Eu anomaly (Eu/Eu* $=0.74$ ) (Table 2; Fig. 6) and have a slightly less prominent $\mathrm{Ce}$ anomaly $\left(\mathrm{Ce} / \mathrm{Ce}^{*}=31.9\right)$ than the megacrysts. The equant zircon has low Sm/La (20.5) ratio and high Lu/Gd ratio (39.0) relative to the megacryst zircon. The brighter luminescent edges of the equant zircon, immediately adjacent to the megacrysts, may have a transitional REE chemistry (total REE $=79$ ppm) between the typical granular zircon and the megacryst zircon that they replace. Thus, they have high HREE concentrations characteristic of the megacryst composition and lower LREE content $(\mathrm{Lu} / \mathrm{Gd}=72.6, \mathrm{Sm} / \mathrm{La}=13.6)$ and have either a 


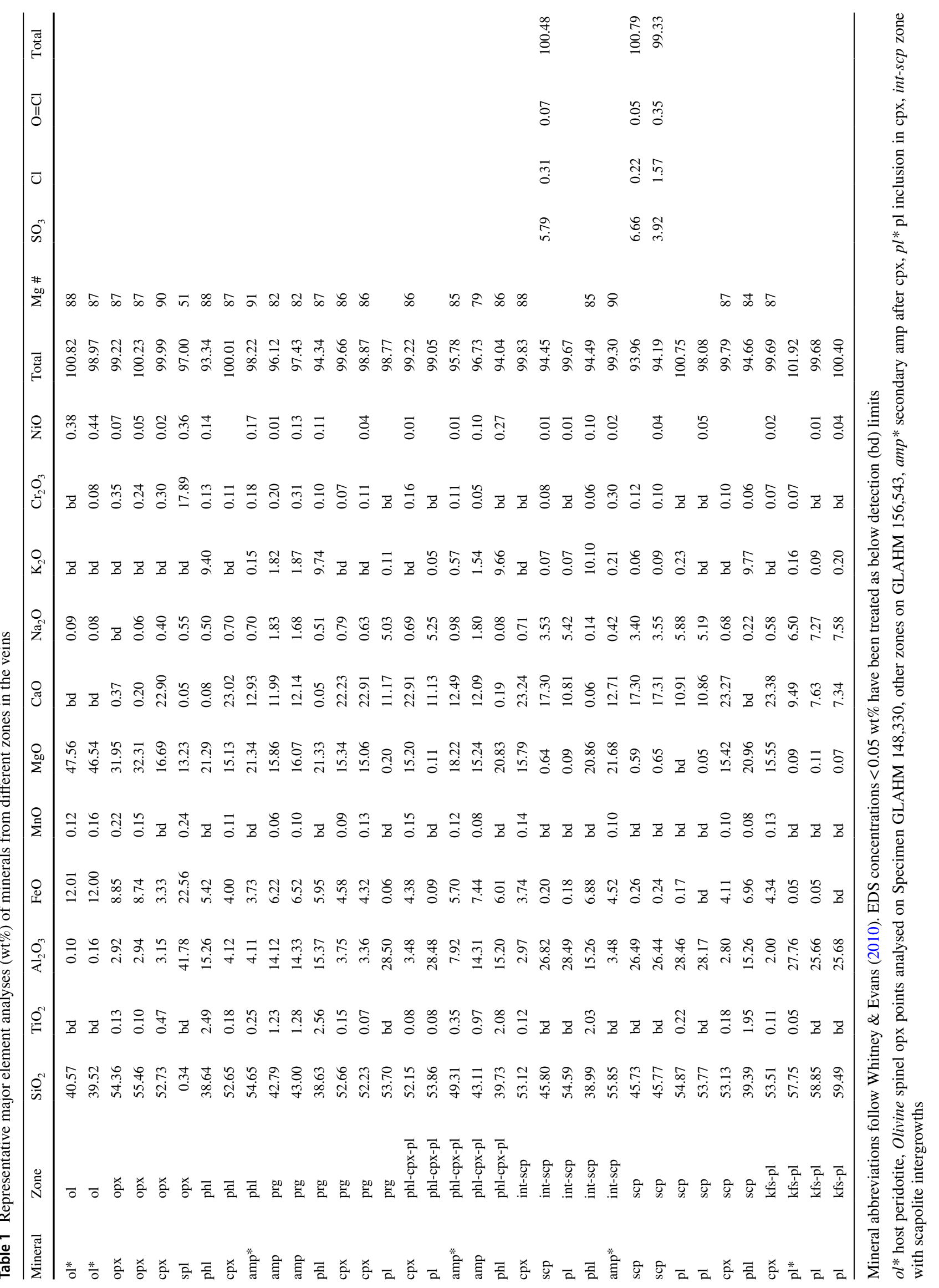




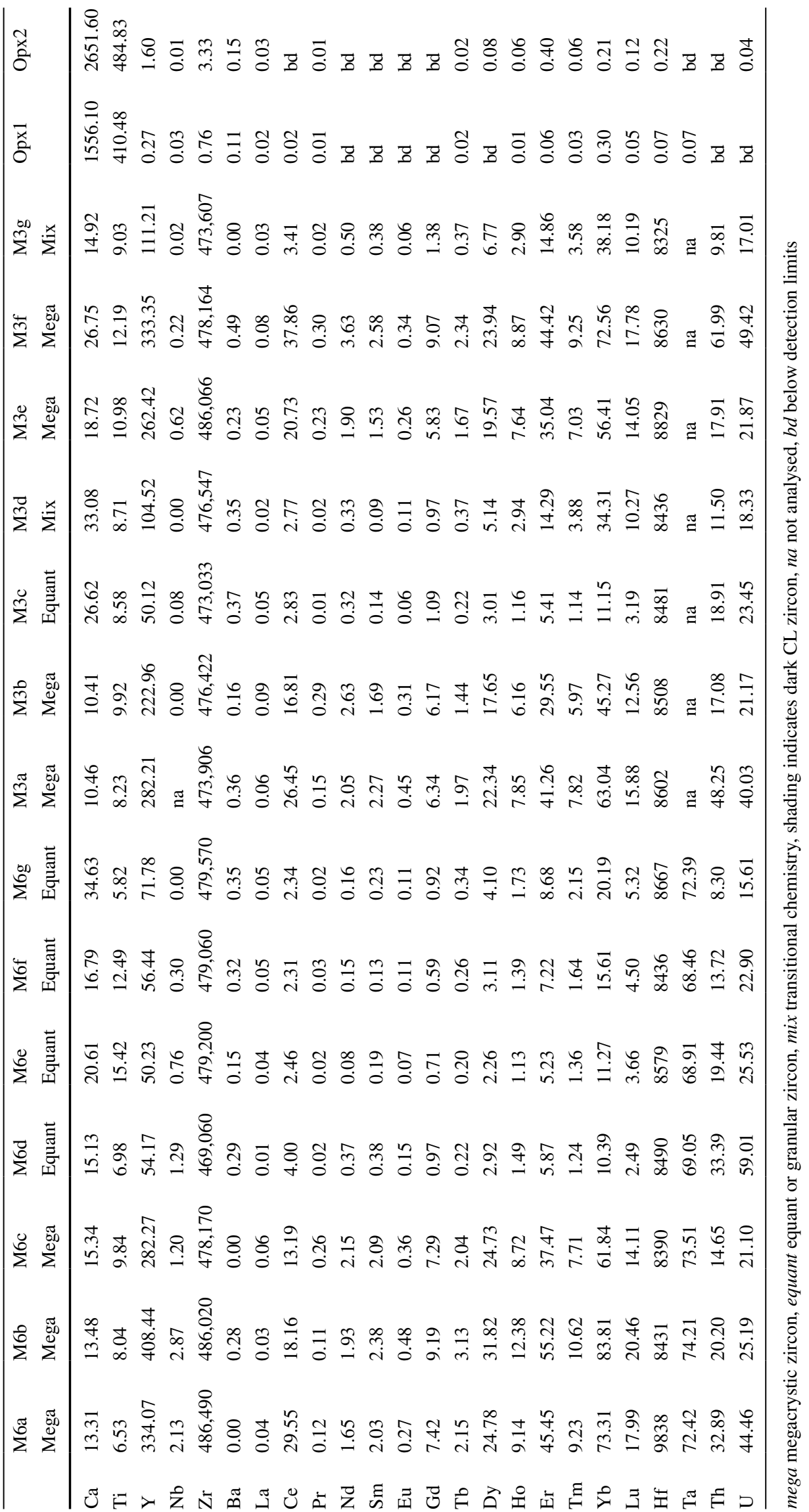


Fig. 6 Chondrite-normalized REE plot, comparing megacryst zircon and equant zircon compositions. Brighter CL rims to the equant population have a transitional composition with HREE similar to the megacrysts and LREE similar to the equant zircon. Partial REE profiles of granoblastic orthopyroxene also shown, some LREE are below detection limits. Compositions of zircon from Lewisian mafic gneisses (MacDonald et al. 2015); low pressure metamorphic zircon (Rubatto and Hermann 2007) and zircon from depleted mantle source (RoblesCruz et al. 2012) are shown for comparison

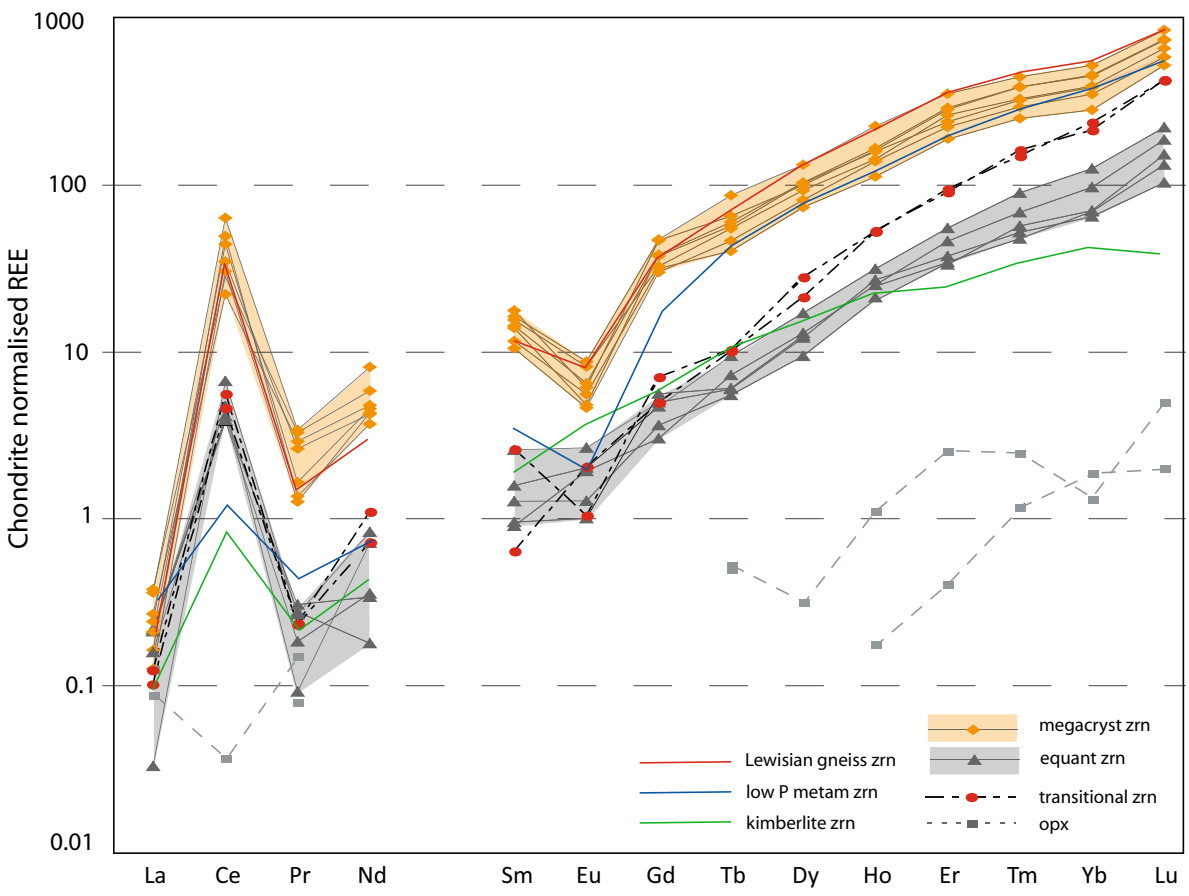

small negative Eu anomaly or lack a Eu anomaly (Fig. 6; Table 2). The latter features are characteristic of the equant zircon. The equant zircon has a similar range of $\mathrm{Ti}$ contents to the megacrysts (5.8-15.4 ppm). Actinide contents of the equant zircon are very similar to those of the megacrystic forms, with greater variation between dark and bright luminescent zircon within a single textural type than between different textural types.

\section{Oxygen isotopes}

The oxygen isotopic values of the megacrystic $\left(\delta^{18} \mathrm{O}\right.$ $=6.72 \pm 0.37 \% \circ 2 \sigma$ error $)$ and equant zircon $\left(\delta^{18} \mathrm{O}=\right.$ $6.82 \pm 0.55 \%$ ) are identical (Table 3; Fig. 7). Although the megacrysts do show some internal variation, it is not linked to any obvious spatial constraints or CL-defined zones. Different megacrysts appear to have identical average oxygen isotopic values. Equant zircon appears to show variation in isotopic composition with those spatially associated with the two individual megacrysts having possible slight differences in $\delta^{18} \mathrm{O}$ with $7.15 \pm 0.29 \%$ and $6.44 \pm 0.46 \%$ (Fig. 7). Although zircon rim compositions were difficult to analyse due to topographic variation at the edges of grains these yield possibly higher $\delta^{18} \mathrm{O}=$ $7.56 \pm 0.64 \%$ values, irrespective of whether they have a bright or dark CL character. The megacrystic zircon that shows dark CL character typically adjacent to the rims of the grain (i.e. similar to the dark CL rims), has lower $\delta^{18} \mathrm{O}$ $=6.64 \pm 0.25 \%$ o effectively identical to the host megacryst composition (Fig. 7).

\section{$\mathrm{U}-\mathrm{Pb}$ geochronology}

Nearly all $\mathrm{U}-\mathrm{Pb}$ isotopic analyses (Table 4) are within error of the concordia line (Fig. 8) with the whole population recording a weighted average ${ }^{207} \mathrm{~Pb} /{ }^{206} \mathrm{~Pb}$ age of $2464 \pm 8 \mathrm{Ma}(2 \sigma$ error, $n=20, \mathrm{MSWD}=2.8)$. Hence, there is no significant $\mathrm{Pb}$ loss and the $\mathrm{U}-\mathrm{Pb}$ ages are interpreted as dating crystallization of the zircon. The weighted average ${ }^{207} \mathrm{~Pb} /{ }^{206} \mathrm{~Pb}$ age of megacrysts is $2464 \pm 12 \mathrm{Ma}(2 \sigma$ error, $n=11$, MSWD $=3.8$ ), this is within analytical error of the weighted average ${ }^{207} \mathrm{~Pb} /{ }^{206} \mathrm{~Pb}$ age of the equant zircon at $2465 \pm 12 \mathrm{Ma}(2 \sigma$ error, $n=9$, MSWD $=1.8)$ (Fig. 8). Although dark luminescent rim compositions are significantly enriched in both $\mathrm{U}$ and $\mathrm{Th}$, there is no discernable difference in the isotopic ages of these rims. Two of the zircon analyses record younger ages, of these one (M3-8 m) has relatively high common $\mathrm{Pb}$, the other (M3-7 eb) is slightly discordant and was obtained was from the very bright luminescent edge of the equant zircon with a ${ }^{207} \mathrm{~Pb} /{ }^{206} \mathrm{~Pb}$ age of $2418 \pm 19$ Ma.

\section{Interpretation}

\section{Metasomatic origin of veins}

The compositions of the vast majority of veins are not representative of liquid compositions as they are solely composed of orthopyroxene. However, their geometry suggests that they form as a consequence of emplacement of melt or fluid. The transition from the evolved leucomonzonite composition of the central part of the largest veins to ultramafic 
Table 3 Oxygen isotope data for megacrysts and equant zircon (M3 and M6, Fig. 4)

\begin{tabular}{|c|c|c|c|}
\hline \multicolumn{2}{|l|}{ M6 large megacryst } & \multicolumn{2}{|c|}{ M3 large megacryst } \\
\hline Grain spot & $\delta^{18} \mathrm{O}(\% \circ)$ & Grain spot & ${ }^{18} \mathrm{O}(\%)$ \\
\hline M6 m21 & 7.30 & M3 m37 & 6.27 \\
\hline M6 m22b & 7.84 & M3 m42 & 6.70 \\
\hline M6 m23 & 7.07 & M3 m43 & 7.31 \\
\hline M6 m24 & 6.56 & M3 m36d & 6.40 \\
\hline M6 m25 & 6.33 & & \\
\hline M6 m28 & 6.88 & M3 equant & \\
\hline M6 m29 & 6.67 & Grain spot & $\delta^{18} \mathrm{O}(\% \circ)$ \\
\hline \multirow[t]{2}{*}{ M6 m30 } & 7.10 & M3 e31 & 6.56 \\
\hline & & M3 e $32 b$ & 7.07 \\
\hline M6 small megacrysts & & M3 e 33 & 6.26 \\
\hline Grain spot & $\delta^{18} \mathrm{O}(\% o)$ & M3 e34 & 6.28 \\
\hline M6 ms2d & 6.76 & M3 e $35 b$ & 6.43 \\
\hline M6 ms3d & 6.46 & M3 e38 & 6.23 \\
\hline M6 ms4 & 6.44 & M3 e39 & 5.93 \\
\hline M6 ms5 & 6.76 & M3 e40 & 7.39 \\
\hline M6 ms6 & 6.18 & M3 e41b & 8.74 \\
\hline M6 ms7d & 7.02 & & \\
\hline M6 ms8 & 6.37 & & \\
\hline M6 ms9d & 6.55 & & \\
\hline M6 ms10do & 7.57 & & \\
\hline M6 ms11do & 7.08 & & \\
\hline M6 ms26do & 6.13 & & \\
\hline M6 ms27 & 6.85 & & \\
\hline \multicolumn{4}{|l|}{ M6 equant } \\
\hline Grain spot & $\delta^{18} \mathrm{O}(\% \circ)$ & & \\
\hline M6 e12 & 6.87 & & \\
\hline M6 e13 & 7.55 & & \\
\hline M6 e14 & 7.10 & & \\
\hline M6 e15 & 7.13 & & \\
\hline M6 e16b & 7.75 & & \\
\hline M6 e17 & 7.37 & & \\
\hline M6 e18 & 6.87 & & \\
\hline M6 e19 & 7.59 & & \\
\hline M6 e20 & 6.86 & & \\
\hline
\end{tabular}

Bright (b) CL rims

Dark (d) CL rims and overgrowths (o)

orthopyroxenite at the margins occurs on the scale of a few centimetres (Fig. 3). Hence, the former is unlikely to represent the end product of an extreme fractionation process of an ultramafic parental melt. The mineralogy of the evolved component of the vein is most compatible with crystallization from a Si-rich melt composition. The introduction of such a melt into peridotite, will allow metasomatic interaction between the Si-rich melt and the olivine in the solid-state ultramafic host. The system is dominated by a forsterite breakdown reaction to produce orthopyroxene at

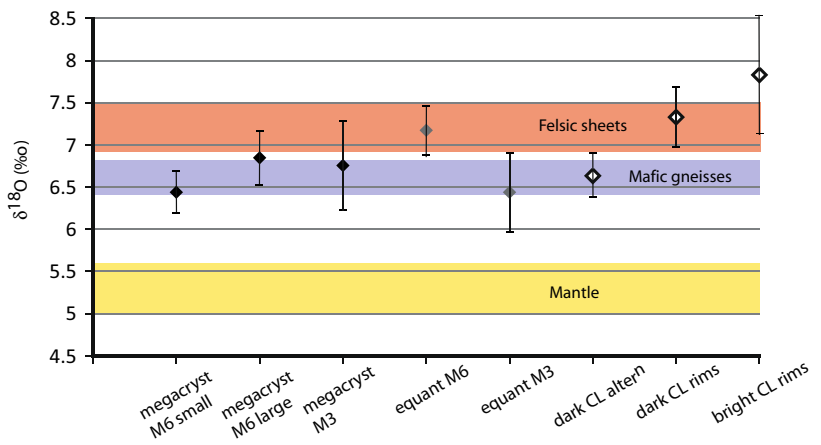

Fig. 7 Average oxygen isotopic compositions of different textural types of zircon, with comparison to published analyses of zircon from mantle reservoirs from Valley et al. (1998) and Lewisian mafic gneisses and felsic melts (Cartwright and Valley 1992)

the margins of the veins. Similar mineralogical sequences to those observed at Loch an Daimh Mor are recorded by Sekine and Wyllie (1982) in mixing peridotite and granite at $30 \mathrm{~kb}$ producing abundant phlogopite and enstatite.

The zoned structure of the veins with low variance mineral assemblages and indeed the scale of this zoning are typical of that generated by metasomatic processes (Arai 1975; Sanford 1982; Barton et al. 1991; Vrijmoed et al. 2013). As such, the leucomonzonite is thought likely to represent the least modified component of the vein material, although the extent of metasomatism is such that the composition of the original melts will be difficult to assess. The larger veins record the most complete sequence of assemblages from more ultramafic compositions to the central more evolved feldspathic compositions. Significant subsolidus transformations are thought to occur within the zoned veins, such as the partial replacement of clinopyroxene by pargasite and the symplectite reaction textures that produce phlogopite in the internal parts of the structure. The overall volumes of melt introduced into the peridotite were probably not especially large, given the scale of the orthopyroxenite veins and the paucity of felsic components. Such volumes are particularly difficult to assess given the uncertainty in the positions of the original margins of the melt conduits, which are masked by the metasomatic transformation of the host peridotite to orthopyroxenite.

\section{Origin of the zircon megacrysts}

The well-shaped oscillatory zoning around a euhedral core and the similarly euhedral shape of the megacrysts (Fig. 4) indicate that all major stages of the zircon megacryst growth occurred within a fluid or melt phase. As such there is no evidence of any inherited components to the megacrysts. This is supported by the $\mathrm{U}-\mathrm{Pb}$ age of the megacryst cores being identical to the age of the rims (Table 4). The textural characteristics of the megacrysts are similar to those 


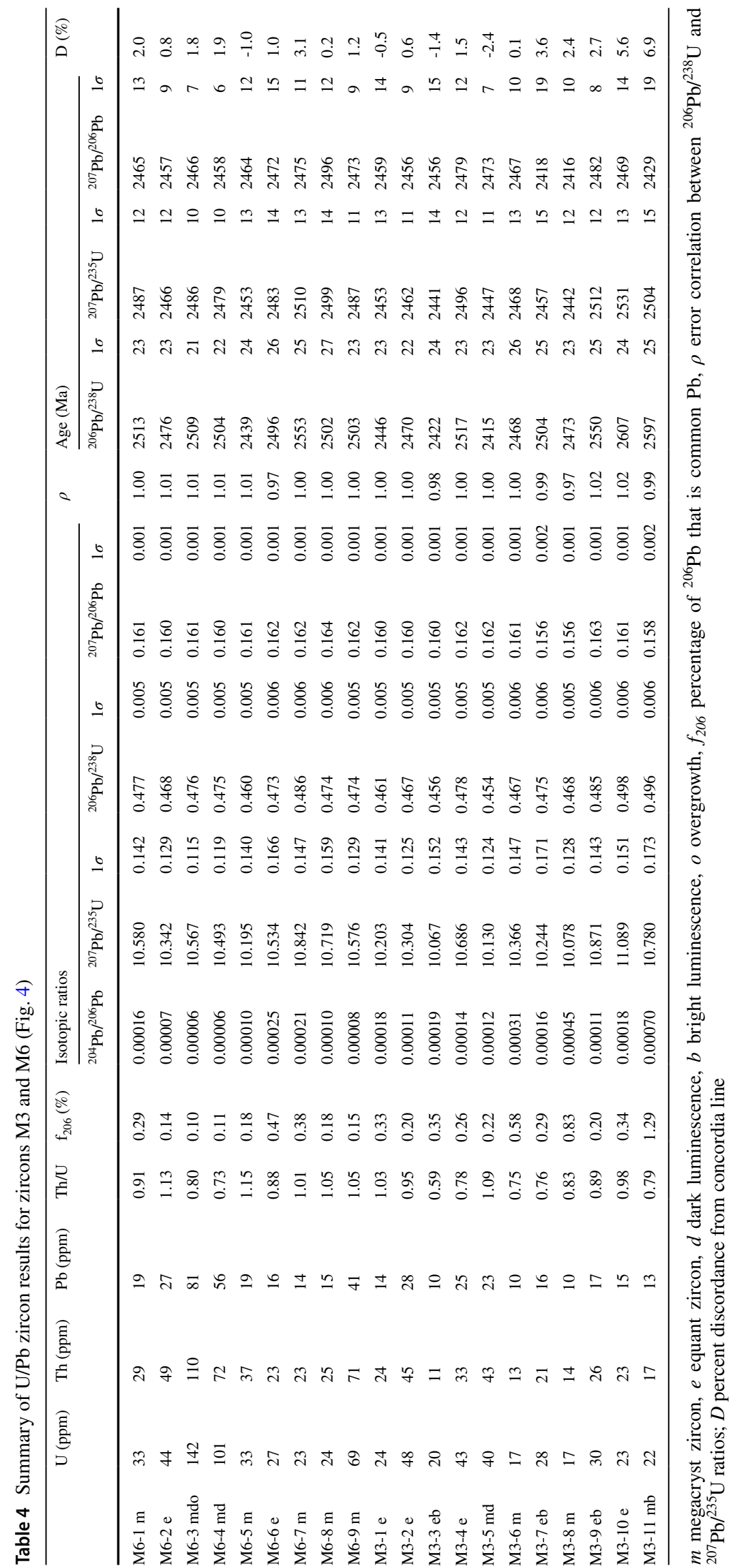




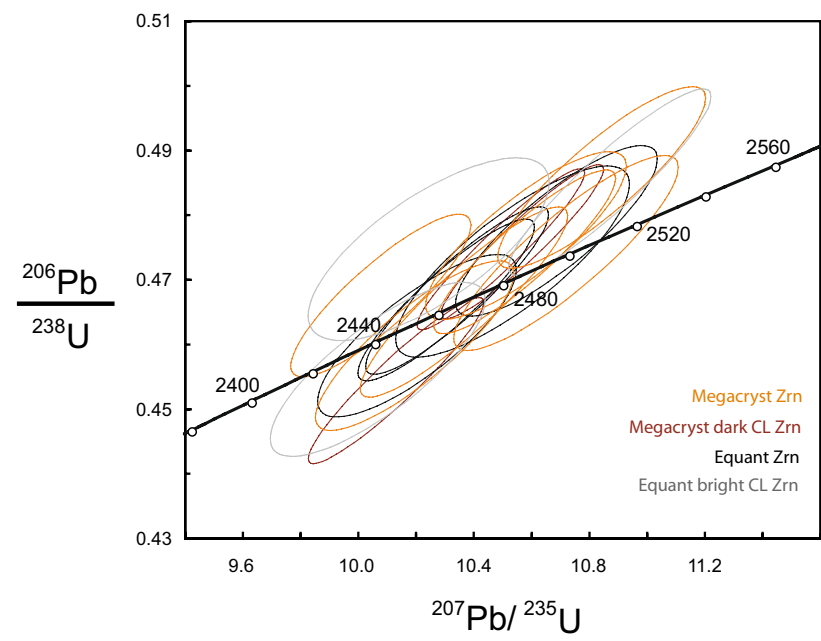

Fig. $8 \mathrm{U}-\mathrm{Pb}$ concordia plot of both megacrystic and equant zircons with $2 \sigma$ error ellipses.

of kimberlitic zircon (Belousova et al. 1998; Corfu et al. 2003) with both a large size, mosaic texture generated by abundant fractures associated with brittle behaviour, and some multistage but often rather poorly developed zoning. The complex zoning observed in the Loch an Daimh Mor megacryst zircon in our investigation contrasts with the large uniform zircon with no primary growth zoning studied by Timms and Reddy (2009) from the same locality.

The scale of both the zircon megacrysts and equant grains, together with the nature of the growth zoning that is preserved and the consistent geochemical and isotopic signatures of both populations, suggests that they preserve significant elements of their growth chemistry. Although aspects of resetting do occur, as discussed in later sections, these appear to be limited to discrete fractures and some small-scale variations associated with grain edges (Fig. 4). As a result, much of the character of the zircon is independent of the later deformation and alteration events that have modified the CL signatures. Generally, the total REE and $\mathrm{Y}$ contents of the megacrysts are higher than those typical of zircon from mantle assemblages (Fig. 6) (Belousova et al. 1998) and low in comparison to zircons from crustal lithologies (Rubatto and Hermann 2007). However, the overall REE patterns are comparable to zircon in some high grade gneisses (Hoskin and Ireland 2000; Whitehouse 2003), including those from mafic gneisses in the immediate vicinity (Fig. 6) (MacDonald et al. 2015). Oxygen isotopic compositions of the non-rim zircon $(6.73 \pm 0.42 \%$ o $)$ are distinct from zircon that is derived from probable mantle-like sources (Fig. 7), which have $\delta^{18} \mathrm{O}$ compositions of $5.3 \pm 0.3 \%$ o (Valley et al. 1998; Valley 2003). Both the megacrysts and the equant type zircon have $\delta^{18} \mathrm{O}$ values similar to those of the Lewisian mafic gneisses (6.4-6.8\%o) (Cartwright and Valley 1992) that surround the peridotites
(Fig. 7). Such gneisses also have very similar $\delta^{18} \mathrm{O}$ compositions to those of the felsic sheets (6.9-7.5\% ) that are within the Scourian gneisses nearby (Cartwright and Valley 1992). Given the lack of isotopic fractionation during melting (Taylor and Shephard 1986), these sheets are likely to be derived by anatexis of the host orthogneisses during peak granulitefacies metamorphism (Cartwright and Valley 1992). A small ultrabasic (hornblendite) pod from near Geodh' nan Sgadan, ca $2 \mathrm{~km} \mathrm{SW}$ of the present sample site, was also analysed by Cartwright and Valley (1992) and yielded lower $\delta^{18} \mathrm{O}$ compositions of 5.5-5.9\%o. As such the isotopic composition of the zircon within the peridotite host is most consistent with derivation from the introduction of crustal melts that were probably sourced from the local gneisses.

The age of the zircon megacrysts determined in this study $(2,464 \pm 12 \mathrm{Ma})$ is within error of previously determined age of 2,451 $\pm 14 \mathrm{Ma}$ (Timms et al. 2006) and is interpreted as a crystallization age, broadly similar to the age of a regional high grade metamorphic event of 2,482 \pm 6 Ma identified by MacDonald et al. (2015). Bands of felsic melt typically permeate the surrounding mafic gneisses (Johnson et al. 2012) and estimated peak metamorphic conditions in the host gneisses are consistent with the production of partial melts (Johnson and White 2011). Consequently, the U-Pb zircon data are compatible with zircon crystallization during the introduction of crustal melts into the peridotite. The time gap associated with these ages is thought unlikely to be significant. In the absence of evidence for rapid exhumation in this time period, it is probably indicative of the prolonged period of time that such lower crustal lithologies may spend at or close to peak metamorphic conditions. The U-Pb ages are consistent with growth of the zircon megacrysts during a granulite-facies, possibly Inverian event.

The zoning textures and shape of the zircon megacrysts, their "crustal-like" geochemistry, rich in REE and other trace elements are all consistent with the introduction of an evolved Si-rich melt phase of crustal affinity (Boehake et al. 2013) into the peridotite. In addition, the negative $\mathrm{Eu}$ anomaly in the zircon megacrysts either indicates the likelihood of contemporaneous plagioclase crystallization (Hoskin et al. 2000) or the melts were depleted in Eu due to plagioclase remaining in the restite of the host gneisses. Zircon megacrysts appear to form as part of an early in situ crystallization sequence associated with orthopyroxene \pm phlogopite in the largest of the veins. A broadly crustal origin raises the possibility that zircons are transported into the peridotite as inherited grains with the siliceous melt. Such origins have been inferred in other examples of zircon within ultramafic host rocks (Liu et al. 2009; Belousova et al. 2015; Li et al. 2016), although these are typically not megacrystic. However, there is no indication of inheritance in the megacrysts and the presence of orthopyroxene and phlogopite inclusions in the zircon 
suggests that they have grown within the veins. The Hf content of the megacrysts is generally compatible with crystallization from a low Si parent melt (Belousova et al. 2002).

The size and local abundance of the zircon must reflect highly mobile components during crystallization and/or locally exceptionally high concentrations of $\mathrm{Zr}$ in the liquid. Modelling indicates that the average amphibolite-facies tonalite composition of Rollinson and Windley (1980) would become nepheline normative after removal of around $30 \%$ $\mathrm{SiO}_{2}$. If $\mathrm{SiO}_{2}$ is the only melt component removed during the metasomatism, and the abundance of orthopyroxenite in all vein margins suggests that $\mathrm{SiO}_{2}$ is the dominant mobile component in the system, peralkalinity will not change significantly. However, $\mathrm{SiO}_{2}$ saturation will change, and miaskitic, nepheline (and potentially, leucite) normative melts may be produced. By itself this process will only produce minor enrichment of $\mathrm{Zr}$ in the remaining Si-undersaturated melt phase. However, it will dramatically change the behaviour of $\mathrm{Zr}$ in the melt, by increasing zircon solubility, suppressing zircon nucleation, promoting depolymerization of the melt (Ni et al. 2015) and allowing melt $\mathrm{Zr}$ levels to build up in residual melts/fluids, such that the megacrysts may form (cf. Schaltegger et al. 2015).

Significant mobility of $\mathrm{Zr}$ within the melt is required to allow the growth of megacrysts and this mobility seems to persist as shown by the late stage crystallization of interstitial zircon in the phlogopite-rich zone (Fig. 3e). Such geochemical mobility is generally compatible with the low variance assemblages in the zoned veins. Scapolite within metasomatic assemblages is commonly reported from other studies to be associated with late replacement of plagioclase in the presence of a volatile-rich fluid (Ekström 1972; Drivenes et al. 2016). S-rich scapolite as found in these assemblages is restricted to granulite-facies rocks (e.g. Lovering and White 1964; Hammerli et al. 2017). The presence of phlogopite in the vein assemblages and the ubiquitous fracturing of zircon grains may also point towards elevated volatile contents. High volatile contents of the melts will enhance HFSE solubility irrespective of melt composition (Antignano and Manning 2008; Rapp et al. 2010; Wilke et al. 2012; Louvel et al. 2014).

Initial crystallization of orthopyroxene occurs before the liquid is saturated in Zr. However, the bulk of zircon is associated with the orthopyroxenite rather than the more evolved fractions of the veins, suggesting that the incoming melt rapidly approaches zircon saturation following initial desilicification. A build up of $\mathrm{Zr}$ in the residual melt might be expected to be linked to an increased concentration of other HFSE. This is not observed in any of the veins, which lack abundant apatite or prominent Ti-bearing minerals, although potentially phlogopite may incorporate some of the likely residual components.

\section{Clustering of megacrystic zircon within the veins}

Overall, the abundance of zircon may not be exceptional, because most of the veins lack zircon. However, locally extreme $\mathrm{Zr}$ contents are recorded (Fig. 2e) and potentially could be caused by three mechanisms:

1. Local emplacement of exceptionally Zr-rich melts

The adjacent TTG gneisses contain textural evidence of partial melting (Johnson et al. 2012) and record granulitefacies metamorphism that post-dates the formation of the peridotites and so provide a potential and proximal source of felsic melts. Melts from Lewisian granulite and amphibolite-facies rocks have average $\mathrm{Zr}$ contents between 100 and 150 ppm (Rollinson and Windley 1980), although a large component of this is probably inherited restitic zircon. Metaluminous to peraluminous granitic melts with over 50-100 ppm Zr will be saturated with zircon (Watson 1979). Consequently, it is difficult to produce melts with higher levels of $\mathrm{Zr}$ by anatexis. If $\mathrm{Zr}$ contents of the melts were $50 \mathrm{ppm}, 100 \mathrm{~kg}$ of melt would contain enough $\mathrm{Zr}$ to form $10 \mathrm{~g}$ of zircon or roughly $0.01 \%$ zircon. Hence, the zircon concentrations in these orthopyroxenite veins are locally more than two or three orders of magnitude greater than would be predicted from a "typical" crustal melt. This coupled with the absence of textural evidence for the emplacement of multiple melts of different compositions argues against the introduction of unusual $\mathrm{Zr}$-rich melts.

\section{Clustered nucleation of zircon}

Reaction with the peridotite wall rocks and desilicification of the felsic melts will ultimately cause those melts to reach zircon saturation. These processes may be locally enhanced by the geometry of the vein systems and the concentration of residual melt. Although the 3D geometry of the network of the veins is hard to assess, zircon appears to be preferentially concentrated in some of the larger veins. Hence, a factor associated with original vein geometry and or width seems most likely to control the clustering of the zircon. Once nucleation has occurred in these veins, $\mathrm{Zr}$ is delivered to these clustered crystals within the remaining melt network in the peridotite. The continued growth will allow the formation of the megacryst clusters. Such localized nucleation and subsequent growth may be characteristic of the other vein components in this metasomatic environment, such as the localized lenses of clinopyroxene.

\section{Clustering of zircon by flow sorting}

A physical accumulation of zircon could occur through either density settling or more probably, given the scale of 
the vein system, via flow sorting. The complex geometry of the veins, the large size of the megacrysts relative to the scale of the veins and the likely crystallinity of the veins at the time of zircon crystallization all apparently mitigate against physical separation of zircon due to the perceived difficulty in maintaining active sustained flow paths. The lack of disturbance to the growth zoning suggests that megacrysts would need to be transported intact within a relatively permeable melt network in which flow is maintained for a prolonged period. They may then preferentially accumulate in parts of the channel network where flow rates are lowered. Crystallization of these veins may be slow, associated with the ambient granulite-facies conditions recorded in the gneisses and the evidence of slow cooling from the coarse grain size of the vein assemblage. However, the occurrence of zircon within a low variance assemblage in isolation of other phases and the lack of alignment suggests that the clustering of megacrystic zircon by flow sorting is unlikely.

\section{Subsolidus behaviour of zircon}

A later stage of zircon growth and recrystallization follows in subsolidus conditions and is represented by clusters of small equant granoblastic zircon around the edge of many megacrysts (Fig. 5). This recrystallization process appears to match that of the co-existing orthopyroxene (Fig. 3a) with the transformation of megacrystic morphologies into granoblastic grains. The zoning and textural characteristics indicate that the equant zircon partly represents a replacement phase (i.e. growth towards the megacrysts) and partly nucleation and growth of new grains in clusters immediately adjacent to the megacrysts. This group of zircon has more metamorphic (solid-state) characteristics with broader zoning and granoblastic textures. The presence of thin bridges of bright luminescent zircon between the two types (Fig. 5d) does indicate that minor growth of the megacrysts may locally continue after the growth of the granular zircon. The $2465 \pm 12 \mathrm{Ma} \mathrm{U}-\mathrm{Pb}$ age of the equant zircon is within error of the age of the megacrysts and hence this recrystallization event must occur during the same broad period of activity, and given the uncertainty in the age determinations within a maximum ca. $23 \mathrm{Ma}$ of the megacryst growth.

The nature of the zircon generated by both recrystallization processes and new growth is distinctive and contrasts with the more irregular-shaped patchy recrystallization that characterizes most low temperature alteration of zircon (Hay and Dempster 2009). Even examples of higher temperature recrystallization reactions (Hermann et al. 2006; Liati and Gebauer 2009) tend to not produce the equant granoblastic zircon associated with the replacement of megacrysts in the orthopyroxenite veins. This may be indicative of a combination of high temperatures and/or long time scales associated with this process.

The later generation of zircon is trace element poor and has a REE chemistry that may be more representative of the peridotite/orthopyroxenite and the less pronounced $\mathrm{Eu}$ anomaly may be indicative of no contemporaneous plagioclase crystallization. The relative depletion of REE in this population could also be indicative of crystallization of amphibole and phlogopite in the vein system. In comparison to zircon from kimberlites, HREE content of the equant zircon are enriched, probably reflecting the absence of co-existing garnet (Rubatto and Hermann 2007). However, generally trace element contents of this population are typical of zircon with mantle-like affinities (Kresten et al. 1975; Belousova et al. 1998; Hoskin and Schaltegger 2003; Robles-Cruz et al. 2012), although the LREE content is higher in the zircon from this study. In part, this may reflect the combination of geochemical inheritance from the adjacent megacryst, an increased influence of the ultramafic host and a reduced influence of the crustal melt that formed the original vein. The equant zircon population reveals evidence of greater heterogeneity of oxygen isotopic compositions than the megacrysts perhaps reflecting crystallization within a less open geochemical environment or more variable later conditions. The outer edge of the equant zircon in contact with the megacryst may have a transitional chemistry with a HREE composition similar to that of the adjacent megacryst and a LREE content similar to that of the rest of the equant grains (Fig. 6). This implies a difference in the mobility of the REE during the recrystallization process, with enhanced mobility of the LREE.

The recrystallization apparently post-dated some of the fracturing that affected the megacrysts, although the megacrysts may be more prone to strain and an inability to rotate. As such determining a history of deformation events solely based on such textural criteria may be difficult. Such deformation events may have enhanced new nucleation in the progressively more crystalline system. A variety of events (e.g. Inverian and Laxfordian) potentially affect both generations of zircon and both zircon growth and chemical modification of the actinide content of zircon may be associated with these events. The actinides appear to be the most mobile of the trace elements within zircon (Timms et al. 2006). The lack of any correlation between REE content and luminescence brightness suggests that rather than a REE-activated CL response (Timms and Reddy 2009), the luminescence in these grains may be more a function of radiation damage. However, the lack of difference in the $\mathrm{U}-\mathrm{Pb}$ isotopic ages suggests that most of this chemical modification occurred shortly after the growth of the zircon and that high temperature conditions persist during brittle deformation of the zircon. Later diffusive modification along grain boundaries occurs associated with the bright luminescent rims to all 
grains and is associated with a late stage fracturing and probably fluid ingress along fractures and grain boundaries. Some of the bright rims are "balanced" by an immediately adjacent dark luminescent zircon so small-scale chemical redistribution of actinides occurs. These have an apparently lower ${ }^{207} \mathrm{~Pb} /{ }^{206} \mathrm{~Pb}$ age of ca. $2,418 \pm 19 \mathrm{Ma}$ and are possibly related to the time of Scourie dyke emplacement. The slightly higher $\delta^{18} \mathrm{O}$ values that appear to characterize the rim compositions might also be broadly consistent with trends observed within the retrograde Inverian events within the host gneisses (Harmon 1983; Cartwright and Valley 1992). Fracturing is also localized around grain edges with a variety of fracture morphologies. Curved fractures centred around a point on the zircon surface, are interpreted to result from the impact of adjacent strong minerals acting as point sources. The last obvious phase of deformation is associated with large fractures that are serpentine-filled with up to mm-scale displacement with fragments of zircon within the serpentine.

\section{Discussion}

The presence of zircon in ultramafic assemblages is reported from a number of different environments (Kresten et al. 1975; Rubatto and Hermann 2003; Hermann et al. 2006; Page et al. 2007; Marrochi et al. 2009; Yang et al. 2016), however, it is typically associated with crystallization in silicic melts of broadly crustal affinity (Hoskin and Schaltegger 2003). As such its potential role in ultramafic rocks is perhaps not widely appreciated. The pyroxenite veins at Loch an Daimh Mor are associated with metasomatic reaction between crustal-derived $\mathrm{Si}$-rich melts and a peridotite host, resulting in melt desilicification and suppression of zircon saturation, and enhanced $\mathrm{Zr}$ mobility within the $\mathrm{Si}$ undersaturated melts. In these high temperature conditions, melt networks remain open for an extended time to allow for the physical concentration, or prolonged growth of zircon megacrysts in parts of the vein network. The textures and geochemistry of the megacrysts bear comparison with others reported from ultramafic hosts (Belousova et al. 1998; Marocchi et al. 2009) and suggest similar origins.

Zircon may potentially have a variety of modes of formation within the mantle (Valley et al. 1998; Liu et al. 2009; Belousova et al. 2015) but studies typically infer an element of metasomatism with a wide variety of proposed metasomatic melts/fluids (Dawson et al. 2001; Mirnejad and Bell 2006). Those from kimberlites all appear to form in similar metasomatic environments and display a continuum of geochemical characteristics (Page et al. 2007). Zircon from the Loch an Daimh Mor peridotites is texturally and geochemically similar to those of mantle xenolith zircon sampled by kimberlites with generally elevated REE contents (Hoskin and Ireland 2000; Konzett et al. 2000) but the latter lack the prominent $\mathrm{Eu}$ anomaly due to the absence of plagioclase in the deep mantle. The equant zircon has a REE geochemistry more similar to those from relatively depleted mantle sources (Robles-Cruz et al. 2012), although with an enriched HREE content. Ti levels are also generally compatible with those from a mantle origin (Page et al. 2007). Mosaic-like textures with fracture-related domains within the zircon megacrysts appear to be similar to those from kimberlite zircon, which are also typically megacrystic (Corfu et al. 2003). This may imply a similar mode of formation and reflect the relative rheology of peridotite host and zircon.

Metasomatic mineral assemblages similar to those in the Lewisian complex are reported from various Alpine peridotites (Zanetti et al. 1999; Markl et al. 2003; Scambelluri et al. 2006; Liati and Gebauer 2009) with interaction between the ultramafic rocks and crustal melts. In a similar context, Marocchi et al. (2009) document zircon megacrysts associated with reactions between peridotite and adjacent crustal gneisses. Metasomatic interactions of this type should in theory be common at subduction zones with crustal slabderived components infiltrating the mantle wedge from either partial melts or fluids derived from of the slab itself (Prouteau et al. 2001) or from the introduction of subducted sediments (Currie et al. 2007). Zircon, and/or strongly Zrenriched melts may be produced in such interactions and should be considered with respect to geochemical budgets (Sorensen and Grossman 1993). Crystallization of zircon will deplete melts in HFSE such as $\mathrm{Zr}$ and Hf (cf. Kelemen et al. 1990; Thirlwall et al. 1994) and such depletions have been linked to a range of models explaining the geochemistry of arc magmas (e.g. Stern and Kilian 1996; Peate et al. 1997; Münker et al. 2004). In this respect, our findings may have significance in demonstrating the stability of zircon in metasomatised ultramafic rocks (Louvel et al. 2013).

Second, our results have significance to the scales of geochemical heterogeneity and mobility during metasomatic processes (Louvel et al. 2013). The localized clustering of dense megacrystic zircon within narrow vein systems generates significant heterogeneity of HFSE distribution within the ultramafic host. This is notable, given the likely introduction of just a single pulse of melt, but also emphasizes the probable longevity of such melt systems at depth. This is complemented by the enhanced geochemical mobility in the Si-undersaturated melts but contrasts with the limited geochemical mobility in the sub-solidus state. Thus, oxygen isotopic ratios record a transition between homogeneous open system behaviour and heterogeneous compositions in the equant zircon as the melt channels progressively crystallize. In contrast, REE concentrations are largely decoupled from the HFSE, although the LREE show evidence of slightly more enhanced mobility than the HREE during these subsolidus processes. Such behaviour confirms decoupling of 
HFSE from REE (Rubatto and Hermann 2003) and decoupling of LIL from HFSE during metasomatism (Griffin et al. 1996).

Third, despite the likely prolonged and high temperature history of the zircon, the original trace element signatures of the zircon remain largely intact during subsequent alteration and deformation. Ironically, given the reputation of geochemical robustness of zircon is built around the preservation of old $\mathrm{U}-\mathrm{Pb}$ ages (e.g. Wilde et al. 2001), it is only the actinides that appear to have been disturbed by the later deformation events (Timms et al. 2006; Piazolo et al. 2016).

Acknowledgements Richard Hinton and John Craven are thanked for their help with analyses and sample preparation at Edinburgh Ion Microprobe Facility. These analyses were supported by NERC facilities grants (IMF610/1016). Peter Chung and John Gilleece are thanked for technical support at the University of Glasgow. Andy Moffat is thanked for introducing JWF to the locality. Taus Jørgensen is thanked for the very detailed and helpful review.

Open Access This article is distributed under the terms of the Creative Commons Attribution 4.0 International License (http://creativeco mmons.org/licenses/by/4.0/), which permits unrestricted use, distribution, and reproduction in any medium, provided you give appropriate credit to the original author(s) and the source, provide a link to the Creative Commons license, and indicate if changes were made.

\section{References}

Antignano A, Manning CE (2008) Rutile solubility in $\mathrm{H}_{2} \mathrm{O}, \mathrm{H}_{2} \mathrm{O}-\mathrm{SiO}_{2}$, and $\mathrm{H}_{2} \mathrm{O}-\mathrm{NaAlSi}_{3} \mathrm{O}_{8}$ fluids at $0.7-2.0 \mathrm{GPa}$ and $700-1000{ }^{\circ} \mathrm{C}$ : implications for mobility of nominally insoluble elements. Chem Geol 255:283-293

Arai S (1975) Contact metamorphosed dunite-harzburgite complex in the Chugoku district, western Japan. Contrib Mineral Petrol 52:1-16

Barton MD, Ilchik RP, Marikos MA (1991) Metasomatism. Rev Mineral 26:321-350

Belousova EA, Griffin WL, Pearson NJ (1998) Trace element composition and cathodoluminescence properties of southern African kimberlitic zircons. Mineral Mag 62:355-366

Belousova EA, Griffin WL, O'Reilly SY, Fisher NI (2002) Igneous zircon: trace element composition as an indicator of source rock type. Contrib Mineral Petrol 143:602-622

Belousova EA, Jiménez JMG, Graham I, Griffen WL, O’Reilly SY, Pearson N, Martin L, Craven S, Talavera C (2015) The enigma of crustal zircons in upper-mantle rocks: clues from the Tumut ophiolite, southeast Australia. Geology 43:119-122

Boehnke P, Watson EB, Trail D, Harrison TM, Schmitt AK (2013) Zircon saturation re-visited. Chem Geol 351:324-334

Bowes DR, Wright AE, Park RG (1964) Layered intrusive rocks in the Lewisian of the North-West highlands of Scotland. Q J Geol Soc Lond 120:153-192

Cartwright I, Barnicoat AC (1987) Petrology of Scourian supracrustal rocks and orthogneisses from Stoer, NW Scotland: implications for the geological evolution of the Lewisian complex. In: Park RG, Tarney J (eds) Evolution of the Lewisian and comparable high grade terrains. Geol Soc Lond Spec Publ 27: 93-107
Cartwright I, Valley JW (1992) Oxygen-isotope geochemistry of the Scourian complex, northwest Scotland. J Geol Soc Lond 149:115-125

Corfu F, Heaman LM, Rogers G (1994) Polymetamorphic evolution of the Lewisian complex, NW Scotland, as recorded by $\mathrm{U}-\mathrm{Pb}$ isotopic compositions of zircon, titanite and rutile. Contrib Mineral Petrol 117:215-228

Corfu F, Hanchar JM, Hoskin PWO, Kinny P (2003) Atlas of zircon textures. Rev Mineral 53:468-500

Crowley QG, Key R, Noble SR (2015) High-precision U-Pb dating of complex zircon from the Lewisian Gneiss Complex of Scotland using an incremental CA-ID-TIMS approach. Gondwana Res 27:1381-1391

Currie CA, Beaumont C, Huismans RS (2007) The fate of subducted sediments: a case for backarc intrusion and underplating. Geology 35:1111-1114

Davies FB (1974) A layered basic complex in the Lewisian south of Loch Laxford, Sutherland. J Geol Soc Lond 130:279-284

Davies JHFL, Heaman LM (2014) New U-Pb baddeleyite and zircon ages for the Scourie dyke swarm: A long-lived large igneous province with implications for the Paleoproterozoic evolution of NW Scotland. Precamb Res 249:180-198

Dawson JB, Hill PG, Kinny PD (2001) Mineral chemistry of a zircon-bearing, composite, veined and metasomatised upper-mantle peridotite xenolith from kimberlite. Contrib Mineral Petrol 140:720-733

Drivenes K, Sørensen BE, Larsen RB (2016) Orogenic degassing, scapolitization and K-metasomatism during Caledonian exhumation, Helgeland, Norway. Norwegian J Geol 96:1-22

Ekström TK (1972) Coexisting scapolite and plagioclase from two iron formations in northern Sweden. Lithos 5:175-185

Evans CR (1965) Geochronology of the Lewisian basement near Lochinver. Sutherl Nat 207:54-56

Ford FD, Skippen GD (1997) Petrology of the Flinton Creek metaperidotites: enstatite-magnesite and anthophyllite-magnesite assemblages from the Grenville province. Canad Mineral 35:122 $1-1236$

Friend CRL, Kinny PD (1995) New evidence for protolith ages of Lewisian granulites, northwest Scotland. Geology 23:1027-1030

Goodenough KM, Crowley QG, Krabbendam M, Parry SF (2013) New $\mathrm{U}-\mathrm{Pb}$ age constraints for the Laxford Shear Zone, NW Scotland: Evidence for tectono-magmatic processes associated with the formation of a Paleoproterozoic supercontinent. Precamb Res 233:1-19

Griffin WL, Smith D, Ryan CG, O'Reilly SY, Win TT (1996) Trace element zoning in mantle minerals: Metasomatism and thermal events in the upper mantle. Canad Mineral 34:1179-1193

Guice GL, McDonald I, Hughes HSR, MacDonald JM, Blenkinsop TG, Goodenough KM, Faithfull JW, Gooday RJ (2018) Re-evaluating ambiguous age relationships in Archean cratons: Implications for the origin ofultramafic-mafic complexes in the Lewisian Gneiss Complex. Precamb Res 311:136-536

Hammerli J, Kemp AIS, Barrett N, Wing BA, Robewrts M, Arculus RJ, Boivin P, Nude PM, Rankenburg K (2017) Sulfur isotope signatures in the lower crust: a SIMS study on S-rich scapolite of granulites. Chem Geol 454:54-66

Harmon RS (1983) Oxygen and strontium isotope evidence regarding the role of continental crust in the origin and evolution of the British Caledonides. In: Atherton MP, Gribble CD (eds) Migmatites, Melting, and Metamorphism, Shiva, Nantwich, 62-79

Hay DC, Dempster TJ (2009) Zircon behaviour during low temperature metamorphism. J Petrol 50:571-589

Heaman LM, Tarney J (1989) U-Pb baddeleyite ages for the Scourian dyke swarm, Scotland: evidence for two distinct intrusion events. Nature 340:705-708 
Hermann J, Rubatto D, Trommsdorff V (2006) Sub-solidus Oligocene zircon formation in garnet peridotite during fast decompression and fluid infiltration (Duria, Central Alps). Mineral Petrol 88:181-206

Hinton RW (1999) NIST SRM 610, 611 and SRM 612, 613 multi-element glasses: constraints from element abundance ratios measured by microprobe techniques. Geostand News J Geostand Geoanal 23(2):197-207

Hoskin PWO, Ireland TR (2000) Rare earth element chemistry of zircon and its use as a provenance indicator. Geology 28:627-630

Hoskin PWO, Schaltegger U (2003) The composition of zircon and igneous and metamorphic petrogenesis. Rev Mineral 53:27-62

Hoskin PWO, Kinny PD, Wyborn D, Chappell BW (2000) Identifying accessory mineral saturation during differentiation in granitoid magmas: and integrated approach. J Petrol 41:1365-1396

Johnson TE, White RW (2011) Phase equilibrium constraints on conditions of granulite-facies metamorphism at Scourie, NW Scotland. J Geol Soc Lond 168:147-158

Johnson TE, Fischer S, White RW, Brown M, Rollinson HR (2012) Archaean intracrustal differentiation from partial melting of metagabbro-field and geochemical evidence from the central region of the Lewisian complex, NW Scotland. J Petrol 53:1-24

Kelemen PB, Johnson KTM, Kinzler RJ, Irving AJ (1990) High-field strength element depletions in arc basalts due to mantle-melt interaction. Nature 345:521-524

Kelly NM, Harley SL (2005) An integrated textural and chemical approach to zircon geochronology: refining the Archaean history of the Napier Complex, east Antarctica. Contrib Mineral Petrol 149:57-84

Kelly NM, Hinton RW, Harley SL, Appleby SK (2008) New SIMS $\mathrm{U}-\mathrm{Pb}$ zircon ages from the Langavat Belt, South Harris, NW Scotland: implications for the Lewisian terrane model. J Geol Soc Lond 165:967-981

Kinny PD, Friend CRL (1997) U-Pb evidence for the accretion of different crustal blocks to form the Lewisian Complex of northwest Scotland. Contrib Mineral Petrol 129:326-340

Kinny PD, Friend CRL, Love GJ (2005) Proposal for a terrane-based nomenclature for the Lewisian Gneiss Complex of NW Scotland. J Geol Soc Lond 162:175-186

Konzett J, Armstrong RA, Günther D (2000) Modal metasomatism in the Kaapvaal craton lithosphere: constraints on timing and genesis from $\mathrm{U}-\mathrm{Pb}$ zircon dating of metasomatized peridotites and MARID-type xenoliths. Contrib Mineral Petrol 139:704-719

Kresten P, Fels P, Berggren G (1975) Kimberlitic zircons-a possible aid in prospecting for kimberlites. Mineral Deposita 10:47-56

Li H-Y, Chen R-X, Zheng Y-F, Hu Z (2016) The crust-mantle interaction in continental subduction channels: Zircon evidence from orogenic peridotite in the Sulu orogeny. J Geophys Res Solid Earth 121:687-712

Liati A, Gebauer D (2009) Crustal origin of zircon in a garnet peridotite: a study of U-Pb SHRIMP dating, mineral inclusions and REE geochemistry (Erzgebirge, Bohemian Massif). Eur J Mineral 21:737-750

Liu Y, Gao S, Hu Z, Gao C, Zong K, Wang D (2009) Continental and oceanic crust recycling-induced melt-peridotite interactions in the Trans-North China orogeny: $\mathrm{U}-\mathrm{Pb}$ dating, $\mathrm{Hf}$ isotopes and trace elements in zircons from mantle xenoliths. J Petrol 51:537-571

Louvel M, Sanchez-Valle C, Malfait WJ, Testemale D, Hazemann J-L (2013) $\mathrm{Zr}$ complexation in high pressure fluids and silicate melts and implications for the mobilization of HFSE in subduction zones. Geochim Cosmochim Acta 104:281-299

Louvel M, Sanchez-Valle C, Malfait WJ, Cardon H, Testemale D, Hazemann J-L (2014) Constraints on the mobilization of $\mathrm{Zr}$ in magmatic-hydrothermal processes in subduction zones from the in situ fluid-melt partitioning experiments. Am Mineral 99:1616-1625

Lovering JF, White AJR (1964) The significance of primary scapolite in granulitic inclusions from deep-seated pipes. J Petrol 5:195-218

Ludwig KR (2003) User's manual for Isoplot 3.00: a geochronological toolkit for Microsoft Excel (No. 4)

MacDonald JM, Goodenough KM, Wheeler J, Crowley Q, Harley SL, Mariani E, Tatham D (2015) Temperature-time evolution of the Assynt Terrane of the Lewisian Gneiss Complex of Northwest Scotland from zircon $\mathrm{U}-\mathrm{Pb}$ dating and Ti thermometry. Precamb Res 260:55-75

Markl G, Abart R, Vennemann T, Sommer H (2003) Mid-crustal metasomatic reaction veins in spinel peridotite. J Petrol 44:1097-1120

Marocchi M, Mair V, Tropper P, Bargossi GM (2009) Metasomatic reaction bands at the Mt. Hochwart gneiss-peridotite contact (Ulten Zone, Italy): insights into fluid-rock interaction in subduction zones. Mineral Petrol 95:251-272

Mirnejad H, Bell K (2006) Origin and source evolution of the Leucite Hills Lamproites: evidence from Sr-Nd-Pb-O isotopic compositions. J Petrol 47:2463-2489

Moffat A, Starkey RE (2013) Zircon pyroxenite from Upper Badcall, Sutherland, North-west Scotland. J Russell Soc 16:64-67

Münker C, Wörner G, Yogodzinski G, Churikova T (2004) Behaviour of high field strength elements in subduction zones: constraints from Kamchatka-Aleutian arc lavas. Earth Planet Sci Lett 224:275-293

Ni H, Hui H, Steinle-Neumann G (2015) Transport properties of silicate melts. Rev Geophys 53:715-744

Nilsson MKM, Söderlund U, Ernst RE, Hamilton MA, Scherstén A, Armitage PEB (2010) Precise U-Pb baddeleyite ages of mafic dykes and intrusions in southern West Greenland and implications for a possible reconstruction with the Superior craton. Precamb Res 183:399-415

O'Hara MJ (1961) Zoned ultrabasic and basic gneiss masses in the early Lewisian metamorphic complex at Scourie, Sutherland. J Petrol 2:248-276

O'Hara MJ (1965) Origin of ultrabasic and basic gneiss masses in the Lewisian. Geol Mag 102:297-314

Page FZ, Fu B, Kita NT, Fournelle J, Spicuzza MJ, Schulze DJ, Viljoen F, Basei MAS, Valley JW (2007) Zircons from kimberlites: New insights from oxygen isotopes, trace elements, and $\mathrm{Ti}$ in zircon thermometry. Geochim Cosmochim Acta 71:3887-3903

Park RG (1970) Observations on Lewisian chronology. Scott J Geol 6:379-399

Peach BN, Horne J, Gunn W, Clough CT, Hinxman LW (1907) The geological structure of the North West Highlands of Scotland. Mem Geol Surv UK

Peate DW, Pearce JA, Hawkesworth CJ, Colley H, Edwards CMH, Hirose K (1997) Geochemical variations in Vanuatu arc lavas: the role of subducted materials and a variable mantle wedge composition. J Petrol 38:1331-1358

Piazolo S, La Fontaine A, Trimby P, Harley S, Yang L, Armstrong R, Cairney JM (2016) Deformation-induced trace element redistribution in zircon revealed using atom probe tomography. Nature Comm 7:10490

Prouteau G, Scaillet B, Pichavent M, Maury R (2001) Evidence for mantle metasomatism by hydrous silicic melts derived from subducted oceanic crust. Nature 410:197-200

Rapp JF, Klemme S, Butler IB, Harley SL (2010) Extremely high solubility of rutile in chloride and fluoride-bearing metamorphic fluids: an experimental investigation. Geology 38:323-326

Reddy SM, Timms NE, Trimby P, Kinny PD, Buchan C, Blake K (2006) Crystal-plastic deformation of zircon: a defect in the assumption of chemical robustness. Geology 34:257-260 
Rimsa A, Whitehouse N, Johansson L, Piazolo S (2007) Brittle fracturing and fracture healing of zircon: an integrated cathodoluminescence, EBSD, U-Th-Pb, and REE study. Am Mineral 92:1213-1224

Robles-Cruz SE, Escayola M, Jackson S, Galí S, Perrov V, Watangua M, Gonçalves A, Melgarojo JC (2012) U-Pb SHRIMP geochronology of zircon from the Catoca kimberlites, Angola: implications for diamond exploration. Chem Geol 310-311:137-147

Rollinson H (2012) Geochemical constraints on the composition of Archaean lower continental crust: Partial melting in the Lewisian granulites. Earth Planet Sci Lett 351-352:1-12

Rollinson HR, Windley BF (1980) An Archaean granulite-grade tonalite-trondhjemite-granite suite from Scourie, NW Scotland: geochemistry and origin. Contrib Mineral Petrol 72:265-281

Rubatto D, Hermann J (2003) Zircon formation during fluid circulation in eclogites (Monviso, Western Alps): Implications for $\mathrm{Zr}$ and Hf budget in subduction zones. Geochim Cosmochim Acta 67:2173-2187

Rubatto D, Hermann J (2007) Zircon behaviour in deeply subducted rocks. Elements 3:31-35

Sajeev K, Windley BF, Hegner E, Komiya T (2013) High-temperature, high-pressure granulites (retrogressed eclogites) in the central region of the Lewisian, NW Scotland: Crustal-scale subduction in the Neoarchaean. Gondwana Res 23:526-538

Sanford RF (1982) Growth of ultramafic reaction zones in greenschist to amphibolite facies metamorphism. Am J Sci 282:543-616

Scambelluri M, Hermann J, Morten L, Rampone E (2006) Melt- versus fluid-induced metasomatism in spinel to garnet wedge peridotites (Ulten Zone, Eastern Italian Alps): clues from trace element and Li abundances. Contrib Mineral Petrol 151:372-394

Schaltegger U, Ulianov A, Müntener O, Ovtcharova M, Peytcheva I, Vonlanthen P, Vennemann T, Antognini M, Girlanda F (2015) Megacrystic zircon with planar fractures in miaskite-type nepheline pegmatites formed at high pressures in the lower crust (Ivrea Zone, southern Alps, Switzerland). Am Mineral 100:83-94

Sekine T, Wyllie PJ (1982) The system granite-peridotite- $\mathrm{H}_{2} \mathrm{O}$ at 30 kbar, with applications to hybridization in subduction zone magmatism. Contrib Mineral Petrol 81:190-202

Sills JD, Savage D, Watson JV, Windley BF (1982) Layered ultramaficgabbro bodies in the Lewisian of northwest Scotland: geochemistry and petrogenesis. Earth Planet Sci Lett 58:345-360

Sorensen S, Grossman JN (1993) Accessory minerals and subduction zone metasomatism: a geochemical comparison of two mélanges (Washington and California, USA). Chem Geol 110:269-297

Stern CR, Kilian R (1996) Role of the subducted slab, mantle wedge and continental crust in the generation of adakites from the Andean Austral volcanic zone. Contrib Mineral Petrol 123:263-281

Taylor HP, Sheppard SMF (1986) Igneous rocks: I. Processes of isotopic fractionation and isotope systematics. Rev Mineral $16: 227-272$

Teertstra DK, Schindler BL, Sherriff BL, Hawthorne FC (1999) Silvialite, a new sulfate-dominant member of the scapolite group with an Al-Si composition near the $I 4 / m-P 4_{2} / n$ phase transition. Min Mag 63:321-329

Thirlwall MF, Smith TE, Graham AM, Theodorou N, Hollings P, Davidson JP, Arculus RJ (1994) High field strength element anomalies in arc lavas: source or process? J Petrol 35:819-838
Timms NE, Reddy SM (2009) Response to cathodoluminescence to crystal-plastic deformation in zircon. Chem Geol 261:11-23

Timms NE, Kinny PD, Reddy SM (2006) Enhanced diffusion of Uranium and Thorium linked to crystal plasticity in zircon. Geochem Trans 7:10

Valley JW (2003) Oxygen isotopes in zircon. Rev Mineral 53:343-385

Valley JW, Kinny PD, Schulze DJ, Spicuzza MJ (1998) Zircon megacrysts from kimberlite: oxygen isotope variability among mantle melts. Contrib Mineral Petrol 133:1-11

Vrijmoed JC, Austrheim H, John T, Hin RC, Corfu F, Davies GR (2013) Metasomatism in the ultrahigh-pressure Svartberget garnet-peridotite (western Gneiss region, Norway): implications for the transport of crust-derived fluids within the mantle. J Petrol 54:1815-1848

Watson EB (1979) Zircon saturation in felsic liquids: experimental results and applications to trace element geochemistry. Contrib Mineral Petrol 70:407-419

Whitehouse MJ (2003) Rare earth elements in zircon: a review of applications and case studies from the Outer Hebridean Lewisian Complex, NW Scotland. In: Vance D, Müller W, Villa IM (eds) Geochronology: Linking the isotopic record with petrology and textures. Geol Soc Lond Sp Publ 220: 49-64

Whitehouse MJ, Kemp AIS (2010) On the difficulty of assigning crustal residence, magmatic protolith and metamorphic ages to Lewisian granulites: constraints from combined in situ $\mathrm{U}-\mathrm{Pb}$ and $\mathrm{Lu}-\mathrm{Hf}$ isotopes. In: Law RD, Butler RWH, Holdsworth RE, Krabbendam M, Strachan RA (eds) Continental Tectonics and Mountain Building: The Legacy of Peach and Horne vol 335. Geol Soc Publ House

Whitney DL, Evans BW (2010) Abbreviations for names of rock-forming minerals. Am Mineral 95:185-187

Wiedenbeck M, Hanchar JM, Peck WH, Sylvester P, Valley J, Whitehouse M, Kronz A, Morishita Y, Nasdala L, Fiebig J, Franchi I, Girard J-P, Greenwood RC, Hinton R, Kita N, Mason PRD, Norman M, Ogasawara M, Piccoli PM, Rhede D, Satoh H, SchulzDobrick B, Skar O, Spicuzza MJ, Terada K, Tindle A, Togashi S, Vennemann T, Xie Q, Zheng Y-F (2004) Further characterization of the 91500 zircon crystal. Geostand Geoanal Res 28:9-39

Wilde SA, Valley JW, Peck WH, Graham CM (2001) Evidence from detrital zircons for the existence of continental crust and oceans on the Earth 4.4 Gyr ago. Nature 409:175-178

Wilke M, Schmidt C, Dubrail J, Appel K, Borchert M, Kvashnina K, Manning CE (2012) Zircon solubility and zirconium complexation in $\mathrm{H}_{2} \mathrm{O}+\mathrm{Na}_{2} \mathrm{O}+\mathrm{SiO}_{2} \pm \mathrm{Al}_{2} \mathrm{O}_{3}$ fluids at high pressure and temperature. Earth Planet Sci Lett 349-350:15-25

Yang Q-Y, Santosh M, Ganguly S, Arun-Gokul J, Dhanil Dev SG, Tsunogae T, Shalji E, Dong Y, Manikyamba C (2016) Melt-infiltration in Archean suprasubduction zone mantle wedge: Evidence from geochemistry, zircon $\mathrm{U}-\mathrm{Pb}$ geochronology and $\mathrm{Lu}-\mathrm{Hf}$ isotopes from Wynad, southern India. Precamb Res 281:101-127

Zanetti A, Mazzucchelli M, Rivalenti G, Vannucci R (1999) The Finero phlogopite-peridotite massif: an example of subduction-related metasomatism. Contrib Mineral Petrol 134:107-122 